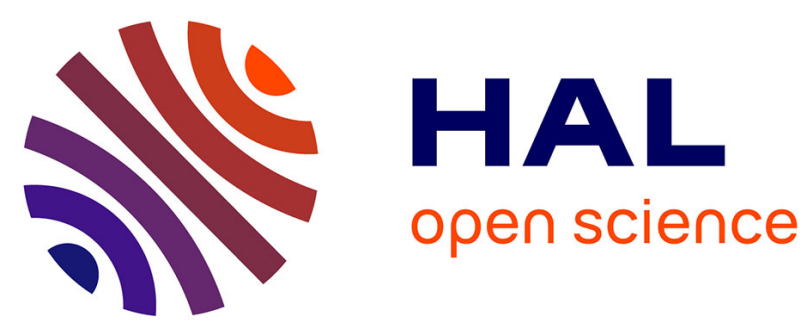

\title{
Impact of the variety on the adsorption of anthocyanins and tannins on grape flesh cell walls
}

Elissa Abi-habib, Aude Vernhet, Stéphanie Roi, Stéphanie Carrillo, Bodil Jørgensen, Jeanett Hansen, Thierry Doco, Céline Poncet-Legrand

\section{- To cite this version:}

Elissa Abi-habib, Aude Vernhet, Stéphanie Roi, Stéphanie Carrillo, Bodil Jørgensen, et al.. Impact of the variety on the adsorption of anthocyanins and tannins on grape flesh cell walls. Journal of the Science of Food and Agriculture, 2022, 102 (8), pp.3379-3392. 10.1002/jsfa.11685 . hal-03477927

\section{HAL Id: hal-03477927 \\ https://hal.inrae.fr/hal-03477927}

Submitted on 13 Dec 2021

HAL is a multi-disciplinary open access archive for the deposit and dissemination of scientific research documents, whether they are published or not. The documents may come from teaching and research institutions in France or abroad, or from public or private research centers.
L'archive ouverte pluridisciplinaire HAL, est destinée au dépôt et à la diffusion de documents scientifiques de niveau recherche, publiés ou non, émanant des établissements d'enseignement et de recherche français ou étrangers, des laboratoires publics ou privés. 
Title: Impact of the variety on the adsorption of anthocyanins and

\title{
tannins on grape flesh cell walls
}

Short Title: Adsorption of tannins and anthocyanins on flesh cell walls

\author{
Elissa Abi-Habib ${ }^{1}$, Aude Vernhet ${ }^{1}$, Stéphanie Roi ${ }^{1}$, Stéphanie Carrillo ${ }^{1}$, Bodil \\ Jørgensen ${ }^{2}$, Jeanett Hansen ${ }^{2}$, Thierry Doco ${ }^{1}$, Céline Poncet-Legrand*1 \\ ${ }^{1}$ SPO, INRAE, Institut Agro, Univ Montpellier, Montpellier, France. \\ ${ }^{2}$ Department of Plant and Environmental Sciences, University of Copenhagen,
} Thorvaldsensvej 40, 1871 Frederiksberg C, Denmark

*Corresponding author:

Phone: $33(0) 499612758$

Fax: $33(0) 499612857$

UMR SPO - Bat 28 - 2, place Pierre Viala - 34060 Montpellier Cedex 2 - France

Email address: celine.poncet-legrand@inrae.fr 


\begin{abstract}
Background During winemaking, after extraction from the skins, anthocyanins and tannins adsorb onto the pulp flesh cell walls. This study aims to quantify the amounts adsorbed and their impact on wine composition, the impact of variety and ethanol on adsorption, and whether the presence of anthocyanins plays a role and impacts tannin adsorption.

Results Anthocyanin and tannin fractions obtained by mimicking winemaking conditions were mixed with fresh flesh cell walls of two varieties: Carignan and Grenache. Adsorption isotherms were measured. Adsorption of tannins was higher with Carignan than with Grenache and decreased when the ethanol content increased. In comparison, anthocyanins were adsorbed in small amounts, and their mixing with tannins had no impact on their adsorption. The differences were related to differences in pulp cell wall composition, particularly in terms of extensins and arabinans.
\end{abstract}

Conclusion Adsorption of tannins, which can reach $50 \%$ of the initial amount, depends on the pulp cell wall composition. This needs to be further investigated.

Keywords: pulp cell walls, adsorption isotherms, interactions, anthocyanins, tannins, Comprehensive Microarray Polymer Profiling 


\section{1- Introduction}

During the red winemaking process, the diffusion of anthocyanins and tannins (or proanthocyanidins (PAs)) is crucial to ensure the expected organoleptic properties of the wine (color, bitterness, astringency...). Previous studies have shown that there is no direct relationship between the phenolic composition in grapes and the corresponding wines ${ }^{1-3}$, whether the phenolic diffusion from grapes was done in a model system or real winemaking conditions.

This is explained by their partial extraction from grape skins and seeds ${ }^{1-5}$, as well as by various processes that take place once these compounds are extracted into the liquid phase: they can chemically react and form new molecules ${ }^{6,7}$, which have different properties than their precursors, interact with yeast insoluble compounds and/or soluble metabolites ${ }^{8,9}$, interact with grapes soluble compounds (polysaccharides, proteins) extracted during maceration ${ }^{10}$, and finally interact with the grapes insoluble cell wall debris suspended in the medium throughout the winemaking process ${ }^{11}$. Most of the studies have focused on the interaction between tannin and cell wall polysaccharides through adsorption experiments using purified cell walls and proanthocyanidins either extracted from grape skins or seeds ${ }^{10-13}$. However, purification and drying procedures may affect the tri-dimensional structure of the network and the accessibility to interaction sites.

In a previous paper ${ }^{5}$, we highlighted the impact of the grape variety and sugar content on the extractability of polyphenols during a model maceration of skins, without the flesh. This was attributed to several differences in the composition of the skin: the anthocyanins present in Grenache and Carignan are different (higher $p$-coumaroylated anthocyanins in Carignan), and diffuse differently; the composition of skin cell walls is different (the cell walls of Carignan are richer in extensins, and those of Grenache are richer in specific hemicelluloses 
(glucans/xyloglucans). On the whole, between 15 and 25\% of the tannins and between 16 and $45 \%$ of the anthocyanins were extracted from skins (diffusion minus losses).

In this study, our objective was to investigate the effect of grape variety and sugar content in the berries on the structural composition (polysaccharides, proteins) of flesh cell walls and therefore on their interactions with anthocyanins and tannins.

Indeed, changes in skin/pulp cell wall composition occur during berry ripening, leading to a loosening of cell walls and fruit softening. Among these changes, a decrease of pectins, related to their solubilization, has been evidenced ${ }^{14,15}$. These structural modifications have been hypothesized to induce changes in skin cell wall structure (porosity, accessibility to interaction sites) and rigidity that may modulate tannin ${ }^{16}$ or anthocyanin extraction ${ }^{17}$. It has also been suggested that anthocyanin may influence tannin extraction/solubility and that high anthocyanin/tannin ratios induce higher tannin concentration in wines, regardless of the initial tannin concentration in fruits ${ }^{18}$.

The choice was made to work with the fresh water-insoluble materials of the flesh (fresh FWIM, mainly cell walls), recovered after extensive washing with an aqueous buffer. To this end, the fresh flesh cell walls of the two different grape varieties, Carignan and Grenache, were recovered from berries at two different ripeness. Interactions were studied in model solutions at 0 and $15 \%$ ethanol through adsorption isotherms, using anthocyanins and tannin fractions extracted from Carignan skins in wine-like conditions. As the objective was to study the impact of fresh FWIM, the same polyphenol fractions were used for the two varieties. Anthocyanins and tannins were first studied separately, then mixed, to assess the competition between anthocyanins and tannins for binding sites. The composition of flesh cell walls was also determined to explain the observed differences. This was performed by means of compositional analysis of sugars and amino acids and Comprehensive Microarray Polymer Profiling 
(CoMPP), a cell wall screening composition technique that characterizes the different families of parietal polysaccharides and glycoproteins ${ }^{19}$.

\section{2- Materials and Methods}

\section{2-1 Chemicals}

Acetonitrile, methanol, ethanol, chloroform, acetic acid, and formic acid were HPLC grade from VWR. Acetone was provided by Fluka. Sodium chloride, tartaric acid, epicatechin, epigallocatechin gallate, lithium chloride, N,N-dimethylformamide, and trifluoroacetic acid were provided by Sigma-Aldrich, sulphuric acid by Roth. Flavanol dimer B2, flavanol trimer C1 and Malvidin-3-O-Glucoside chloride were purchased from Extrasynthese (Genay, France). Ultra-pure water was obtained from a Milli-Q Advantage A10 system (Millipore).

\section{2-2 Grape sampling}

Two Vitis vinifera grape varieties (Carignan and Grenache), of the 2018 season, were harvested at average potential alcohol of $12 \%$ vol. in the vineyard of the Pech Rouge experimental unit (UE-PR, INRAE, Gruissan, France). The berries were harvested at maturity and sorted according to their diameter (vol- for berries with a diameter of less than $1.4 \mathrm{~cm}$, vol+ for berries with a larger diameter), and density as described before (deg-corresponds to berries having the lower content in sugar, whereas deg+ corresponds to berries with the higher content)

5. The flesh was separated with a scalpel and immediately frozen in liquid nitrogen and stored at $-80^{\circ} \mathrm{C}$ for later experiments and analysis of their composition. In this study, the focus was put on the vol+ modality (i.e. the berries having the larger size). The sugar concentrations were $193 \pm 1$ and $240 \pm 2 \mathrm{gL}^{-1}$ for Grenache deg- and deg + , respectively, whereas they were $176 \pm$ 6 and $212 \pm 4 \mathrm{gL}^{-1}$ for Carignan. 


\section{2-3 Biochemical analysis of alcohol insoluble flesh cell wall materials}

Frozen flesh (from 30 berries, triplicate) was ground in liquid nitrogen. The alcohol-insoluble solids (AISs) were isolated first using the same procedure as that described previously for skins for the analysis of neutral and acidic sugars and amino acids ${ }^{5}$. Frozen pulps of each variety and modality (from 30 berries, triplicates) were ground in liquid nitrogen. The alcohol insoluble cell wall solids (AISs) were then isolated from the powders using the procedure described in Apolinar-Valiente et al. ${ }^{20}$, with slight modifications. AISs were prepared in triplicate and analysed separately. Pulp powder $(5 \mathrm{~g})$ was suspended in $15 \mathrm{ml}$ of boiling water for $5 \mathrm{~min}$ and homogenized. One part of the homogenized material was purified with two parts of $96 \%$ ethanol for $30 \mathrm{~min}$ at $40^{\circ} \mathrm{C}$ in an ultrasound bath. The alcohol insoluble solids (AIS) were separated by centrifugation and extracted again with $70 \%$ ethanol for $30 \mathrm{~min}$ at $40{ }^{\circ} \mathrm{C}$. A sample from the liquid phase was taken for soluble sugar assay, done with the sulphuric phenol method. When no more sugar was detected, AISs were further washed twice with $96 \%$ ethanol and once with acetone. After being dried with an air flux overnight, they were weighed and used for the following analyses. The neutral sugar composition of the AISs was determined by gas chromatography after polysaccharide hydrolysis with $72 \%$ sulphuric acid at $100^{\circ} \mathrm{C}$ for $3 \mathrm{~h}$ and conversion of neutral sugars into volatile alditol acetates ${ }^{21,22}$. Inositol and allose were used as internal standards. The alditol acetates were quantified by gas chromatography with flame ionization detection (GC-FID) (GC 2010 Plus Shimadzu) using a DB225 (30 m ×0.25 mm ID, $0.25 \mu \mathrm{m}$ film) capillary column and hydrogen $5.6 \mathrm{~B} 50$ as the carrier gas. Calibration was done with commercial monosaccharides. Uronic acids were determined colorimetrically in triplicates by the $m$-hydroxydiphenyl method ${ }^{23}$. The AISs were first submitted to pre-hydrolyse by the action of sulfuric acid, as described by Ahmed and Labavitch ${ }^{24}$. A calibration curve was built using pure galacturonic acid solutions ( 0 to $100 \mathrm{mg} / \mathrm{L}$ ). The degree of methylesterification of uronic acids (DE) was measured by the saponification of the AIS pectins in the presence of 
$\mathrm{KOH}$, thus allowing the release of methanol. Methanol was converted to formaldehyde that was determined using the colorimetric method of Klavons and Bennet ${ }^{25}$. Amino acids were analysed according to the following procedure: cell wall material $(5 \mathrm{mg})$ was hydrolysed in 1 $\mathrm{mL}$ of $6 \mathrm{~N} \mathrm{HCl}$ for $24 \mathrm{~h}$ at $120^{\circ} \mathrm{C}$. Norleucine was added as an internal standard. After evaporation of the acidic aqueous solution under the air stream, samples were washed twice in water and then in $95 \%$ ethanol. Finally, samples were dissolved in a $0.2 \mathrm{M} \mathrm{pH} 2.2$ lithium citrate loading buffer and filtered through a $0.22 \mu \mathrm{m}$ filter (Millipore Millex-GV). Amino acids were quantified by ion-exchange chromatography with a Biochrom 30 amino acid analyzer (Biochrom, Cambridge, England), as described in Vicens et al. ${ }^{14}$.

\section{2-4 Comprehensive Microarray Polymer Profiling (CoMPP) of flesh cell}

\section{wall materials}

In the second series of experiments, the AIS (from 30 berries, triplicates) were isolated using the following procedure, as the optimal to the CoMPP technology 19,26,27. The frozen ground flesh $(10 \mathrm{~g})$ was incubated in $100 \% \mathrm{v} / \mathrm{v}$ absolute ethanol at $80^{\circ} \mathrm{C}$ for $15 \mathrm{~min}$ to deactivate endogenous enzymes. After centrifugation, the pellets were washed sequentially by a series of solvents (ethanol, methanol, chloroform, and acetone) using a stirring plate. Thereafter, the pellets were suspended in deionized water and freeze-dried to yield dry powders of flesh cell wall materials, which were used for structural composition analysis (CoMPP).

Samples were sequentially extracted first with 50mM CDTA (cyclo-hexane-diaminotetra-acetic acid $\mathrm{pH} 7.5)$ and then with $\mathrm{NaOH}(4 \mathrm{M}){ }^{28}$ to obtain the pectin and hemicellulose rich fractions. After centrifugation, the extracts from each fraction were printed onto a nitrocellulose membrane and then probed with a series of monoclonal antibodies (mAbs) and carbohydrate-binding modules (CBMs), which are listed in Supplementary Table 1. The raw data were normalized and converted into a heatmap for visualization. The relative abundance 
of different polymers epitopes are displayed on a scale of $0-100$, with a cut-off value of 5 on the raw data as described in reference ${ }^{28}$. The values are means from three biological repeats and four dilutions.

\section{2-5 Extraction and purification of Polyphenols from grape skins}

Grape berries of Carignan were defrosted, then the skins were peeled with a scalpel and immersed in model wine-like solutions at $15 \% \mathrm{v} / \mathrm{v}$ ethanol containing $3 \mathrm{gL}^{-1}$ tartaric acid, 50 $\mathrm{mM} \mathrm{NaCl}$, sodium azide $(0.02 \%)$, and $40 \mathrm{mgL}^{-1} \mathrm{SO}_{2}$ (to prevent the oxidation of phenolic compounds), the $\mathrm{pH}$ of which was adjusted at 3.5 with $\mathrm{NaOH} 1 \mathrm{M}$. Flasks were placed under argon and gently stirred in dark at $20{ }^{\circ} \mathrm{C}$ for 3 days. The model solution was then filtered, centrifuged, and concentrated under vacuum at $40^{\circ} \mathrm{C}$ using a rotavapor (RII BUCHI) to eliminate the ethanol. The polyphenol extract was recovered in water and then deposited on a column filled with Fractogel Toyopearl HW-50F (bed volume $226 \mathrm{~cm}^{3}$ ) and connected to a lab-scale chromatography system (Puriflash 430, Interchim) equipped with a UV detector. Phenolic compounds adsorbed on the colum. The column was first rinsed with two bed volumes of distilled water and trifluoroacetic acid (TFA, $0.05 \%$ ) at a flow rate of $7 \mathrm{~mL} \mathrm{~min}^{-1}$ to remove the water-soluble compounds (salts, sugars, amino acids,...). The monomeric fraction (mainly anthocyanins) was eluted with a 55/45 (v/v) ethanol/water solvent acidified with TFA $(0.05 \%)$. The polymeric tannin fraction was then eluted with a 60/40 (v/v) water/acetone solvent acidified with TFA $(0.05 \%)$. Both extracts were evaporated under vacuum at $40{ }^{\circ} \mathrm{C}$ to remove the solvents and recovered with water before freeze-drying. The two fractions (anthocyanins and tannins) were stored at $-80{ }^{\circ} \mathrm{C}$ in sealed vials under argon atmosphere before further use. A sample of each fraction was analysed by UV-Vis spectrophotometry, HPLC, and SEC. The mean degree of polymerization (mDP) of skin tannins was estimated to be around 9 from SEC and by comparison to standards ${ }^{5}$, after plotting the curve $\log (\mathrm{Mw})$ as a function of the elution volume. 


\section{2-6 Adsorption experiments}

Adsorption experiments were performed in 0 and $15 \%$ ethanol model solutions composed of $3 \mathrm{gL}^{-1}$ tartaric acid, $50 \mathrm{mM} \mathrm{NaCl}\left(2.16 \mathrm{gL}^{-1}\right)$ to set the ionic strength, sodium azide $(0.02 \%)$ to prevent bacterial growth, and $40 \mathrm{mgL}^{-1} \mathrm{SO}_{2}$ (to prevent the oxidation of phenolic compounds), the $\mathrm{pH}$ of which was adjusted at 3.5 with $\mathrm{NaOH} 1 \mathrm{M}$.

Each experiment was performed with $1.1 \mathrm{~g}$ of ground frozen fresh flesh for $1 \mathrm{~mL}$ of polyphenol solution. This amount was chosen based on the data of the 2017 and 2018 harvests where $1 \mathrm{~kg}$ of berries led to $700 \mathrm{~mL}$ of wine on average, with the pulp accounting for $80 \%$ of the berry fresh weight. The flesh weighed in a $2 \mathrm{~mL}$ Eppendorf was defrosted at $4{ }^{\circ} \mathrm{C}$ and washed 8 times in the $0 \%$ model solution to eliminate the must and all water-soluble components. After the last centrifugation $\left(15000 \mathrm{~g}, 10 \mathrm{~min}, 4{ }^{\circ} \mathrm{C}\right)$, the absence of soluble sugars and proteins was checked using the sulphuric phenol ${ }^{29}$ and Bradford ${ }^{30}$ methods, respectively. The fresh flesh water-insoluble material (FWIM) was dried by drainage before being weighed again. Fresh FWIM represented about $10 \%$ of the initial flesh weight. It was immediately mixed with $1 \mathrm{~mL}$ of the model solutions at adequate polyphenol concentrations for interaction experiments. Samples were stirred continuously on a rotator (Stuart SB3 $40 \mathrm{rpm}$ ) in darkness and at $20{ }^{\circ} \mathrm{C}$. A solution of polyphenols without FWIM and fresh FWIM suspended in the model solution without polyphenols served as controls. At the end of the experiment, the supernatants were recovered by centrifugation for analysis. The adsorption was quantified from the difference in concentration between the supernatants and the controls (polyphenols solution without FWIM and FWIM suspended in model wine without polyphenols).

Kinetic studies were performed first to determine the contact time required to reach the adsorption equilibrium. These experiments were done at two different anthocyanin and tannin

concentrations $\left(0.1 \mathrm{gL}^{-1}\right.$ and $\left.2 \mathrm{gL}^{-1}\right)$ and in 0 and $15 \%$ ethanol solutions using a fresh FWIM of the Carignan variety. Samples were stirred for 2 days and an aliquot was taken at several time 
intervals $(1,3,6,24,37$, and $48 \mathrm{~h})$. Polyphenol adsorption was followed using absorbency measurements (supplementary Figure 1). It was the difference between the initial concentration in solution and the concentration at time t. After an increase during the first hours, a plateau value was obtained after $24 \mathrm{~h}$ at the higher concentration $\left(2 \mathrm{gL}^{-1}\right)$, indicating that the equilibrium was reached. At low concentration, the plateau was reached during the first hours. From these results, the contact time for adsorption isotherm experiments was set at $30 \mathrm{~h}$.

Adsorption experiments were performed first with the tannin fraction using concentrations ranging from 0.25 to $8 \mathrm{gL}^{-1}\left(0.25,0.5,1,2,4,6,8 \mathrm{gL}^{-1}\right)$ and with the anthocyanin fraction using concentrations ranging from 0.1 to $2 \mathrm{gL}^{-1}\left(0.1,0.25,0.5,1,2 \mathrm{gL}^{-1}\right)$.

Adsorption isotherms were fitted with the SigmaPlot 13.0 by Systat Software, using the ligand-binding model with one or two saturation sites (equation 1 and 2):

$$
y=\frac{B_{\max } x}{K_{d}+x}
$$

where $\mathrm{y}$ is the adsorbed amount of tannins /g of FWIM, $\mathrm{x}$ the equilibrium concentration, $\mathrm{B}_{\max }$ the adsorbed amount corresponding to the saturation (all sites are occupied), $\mathrm{K}_{\mathrm{d}}$ the concentration for which $\mathrm{y}=\mathrm{B}_{\max } / 2$. This formalism is close to Langmuir's ${ }^{31}$ which is valid for the adsorption of perfect gas molecules on a surface, and has been used in systems close to $\operatorname{ours}^{32}$.

The same model can be applied, considering that there are two types of sites accessible to tannins :

$$
y=\frac{B_{\max 1} x}{K_{d 1}+x}+\frac{B_{\max 2} x}{K_{d 2}+x}
$$

where $B_{\max 1}$ and $K_{d 1}$ correspond to the first type of sites and $B_{\max 2}$ and $K_{d 2}$ to the second type of sites. This model was used because cell walls are made of polysaccharide and protein networks, which are known to have very different affinities for tannins.

In another series of experiments, mixtures of anthocyanins and tannins at different concentrations (different anthocyanin/tannin ratios) were used. Two anthocyanin 
concentrations of $0.5 \mathrm{gL}^{-1}$ and $2 \mathrm{gL}^{-1}$ were selected. The former is equivalent to a frequent anthocyanin concentration in wine whereas the latter represents a very high concentration condition. Each of these anthocyanin solutions was mixed with tannins at four different concentrations: $0.5,1,2,4 \mathrm{gL}^{-1}$.

\section{2-7 Reversibility of adsorption}

After adsorption experiments, the FWIMs recovered by centrifugation were dispersed in $1 \mathrm{ml}$ of a model solution without polyphenols. Samples were stirred for $30 \mathrm{~h}$ and the supernatants recovered. The reversibility of the adsorption was determined through the analysis of the polyphenols recovered in the solution.

\section{2-8 Polyphenol analysis}

Total polyphenols Index (TPI) and total red pigments (TRP) were determined by UVvisible spectrophotometry (spectrophotometer UV-1600, Shimadzu) at 280 and $520 \mathrm{~nm}(1 \mathrm{~cm}$ path length) after adequate dilution in $\mathrm{HCl} 1 \mathrm{M}$. HPLC and HPSEC analyses were also performed to distinguish between the adsorption of monomers (free anthocyanins) and that of tannins. Free anthocyanins were analyzed by HPLC using a Waters chromatography system equipped with DAD detection and a C18 reversed-phase column (Atlantis T3, Waters) ${ }^{5}$. Anthocyanins were quantified at $520 \mathrm{~nm}$, in equivalent of malvidin-3-O-glucoside. Tannins and their size distribution in the samples were analyzed by high-pressure size exclusion chromatography (HPSEC) in dimethylformamide with $1 \%$ acetic acid (v/v), 5\% water (v/v), and $0.15 \mathrm{M}$ lithium chloride, at $60^{\circ} \mathrm{C}$, at $1 \mathrm{~mL} \mathrm{~min}{ }^{-1}$, injected in the Agilent HPLC 1260 Infinity II system equipped with a DAD and 2 Phenogel columns connected in series, as detailed in reference ${ }^{5}$. 


\section{2-9 Statistical analysis}

Statistical analysis was done using Statistica software. Experiments were performed in triplicate. The results obtained were assessed by factorial and one-way ANOVA analysis followed by a Tukey Test. Principal Component Analysis was performed on the raw data set of CoMPP results of the AIS pulp cell walls to better evaluate the differences between varieties.

\section{3- Results and Discussion}

\section{3-1 Tannin adsorption by FWIM}

Adsorption isotherms were established in 0 and $15 \%$ ethanol model solutions with Carignan and Grenache fresh FWIMs and the tannin fraction extracted from grape skins in wine-like conditions. These two ethanol contents were chosen although the grapes were harvested at a potential alcohol of $12 \%$, because in our previous experiments we studied the diffusion during a simulated fermentation, and looked at the changes when the percentage of ethanol increased from 0 to $15 \%{ }^{5}$. This final concentration of $15 \%$ was also chosen to emphasize the effect of ethanol content and to compare our results with other experiments ${ }^{33}$. Up to initial concentrations of $0.5 \mathrm{gL}^{-1}$ (initial part of the isotherm), adsorption represented more than $85 \%$ of the initial tannin contents in solution at $0 \%$ ethanol and more than $73 \%$ in $15 \%$ ethanol (Figure 1A and Table 1). No significant differences were observed between the two varieties and modalities. At higher concentrations, a change in slope was observed: adsorbed amounts increased much more progressively. Unlike what was observed at low concentrations, adsorbed amounts were significantly higher with Carignan FWIMs than with Grenache ones, but the sugar content of the berry had no impact. A higher binding was always observed in $0 \%$ ethanol than in $15 \%$, in agreement with previous results ${ }^{33,34}$. This is related to the impact of ethanol on polar interactions (hydrophobic interactions and H-bond formation) and the role of the latter on the solubility and interactions of tannins ${ }^{35,36}$. The reversibility of 
tannin adsorption was not influenced by the adsorbed amount and remained rather low, between 20 and $30 \%$ (Figure 1B). It was higher in the presence of ethanol, in agreement with the impact of this solvent of polyphenol adsorption, and slightly higher for Grenache than for Carignan. This low reversibility does not necessarily reflect a high affinity between tannins and FWIM and may only be related to multiple bonding between tannins and FWIM. Although all tannins in the studied fraction, including di and trimers, were concerned by adsorption at rather high concentrations $\left(4 \mathrm{gL}^{-1}\right)$, HPSEC analyses (Figure 1C and D) indicated that the highest molecular weight tannins were preferentially adsorbed, and that reversibility was related to small tannins.

At low concentrations, lateral interactions between adsorbed species are low and the initial part of the isotherm represents the polymer affinity for the sorbent. As the polymer concentration increases, adsorbed amounts and plateau values (maximum adsorbed amounts) depend on the number of binding sites and of their affinity for the polymer, on the accessibility of these binding sites, and possible conformational rearrangements and lateral interactions between adsorbed polymers. It is worth noting that no plateau was reached in our experimental conditions, and thus for high tannin concentrations compared to those found in winemaking. FWIMs are essentially cell walls, that is complex tri-dimensional networks of different polysaccharides and proteins, with interaction sites having different affinities for tannins ${ }^{18-22}$, and whose accessibility may depend on tannin size. The change in slope observed here in the isotherms may reflect the different nature of these binding sites, and the lack of plateau value even at tannin concentrations as high as $8 \mathrm{gL}^{-1}$ the existence of numerous interaction sites in FWIMs, still accessible at these concentrations for the studied tannins fraction.

Langmuir isotherms were used to describe tannin adsorption on apple or grape cell walls $33,42,43$. Even if the fundamental assumptions related to this model are not fulfilled, curve fitting provides convenient mathematical constants that can be used to compare results between different tannins fractions and different adsorbents. The adsorption isotherms were fitted 
according to two ligand binding models (Figure 1A): one-site saturation, which is mathematically the same as Langmuir's, and two-site saturation. This model was used because cell walls are made of polysaccharides and proteins networks, which are known to have very different affinities for tannins. The whole results are summarized in Table 2. In all cases, the adjusted $\mathrm{R}^{2}$ was better when the two-site model was used, in the range 0.992-0.999 (two sites) vs $0.965-0.979$ (one-site). When the two-site binding model is used, the $\mathrm{Kd}_{2} / \mathrm{Kd}_{1}$ is in the range 160-540, indicating that the first type of sites, have affinities for tannins roughly two orders of magnitude higher than the second type of sites. This ratio is in agreement with isothermal titration calorimetry experiments performed between tannins and polyproline ${ }^{39,40}\left(\mathrm{~K}_{\mathrm{a}}\right.$ in the range $\left.10^{5} \mathrm{M}^{-1}\right)$ and polysaccharides and tannins ${ }^{44}\left(\mathrm{~K}_{\mathrm{a}}\right.$ in the range $\left.10^{3} \mathrm{M}^{-1}\right)$. This may indicate that the first type of sites corresponds to 'protein' sites, and the second one to 'polysaccharide' sites. The supplementary Figure 2 (2-site binding model with 95\% confidence intervals) confirms that the variety and the \% in ethanol lead to significant different adsorptions.

Our results should be compared with those of Beaver et al. ${ }^{33}$, and Bindon et al. ${ }^{43,45}$, who fitted their results with a Langmuir isotherm. This is actually the same model as a one-site saturation binding, except that $\mathrm{K}_{\mathrm{eq}}=1 / \mathrm{K}_{\mathrm{d}}$. However, they used cell walls purified with different techniques, involving phenol buffer extractions that are performed to remove proteins, and dried. They also mainly worked with skin cell walls, which are poorer in proteins ${ }^{5,46}$, and thus have probably less affinity for tannins. In the present work, we have used the flesh waterinsoluble materials, extensively washed with water but not with organic solvents and not dried. To compare with the results of Beaver ${ }^{33}$ and Bindon ${ }^{45}$, our data were processed considering the initial mass of flesh used for each interaction experiment $(1.1 \mathrm{~g})$ and the corresponding values of purified and dried flesh cell wall materials (AIS, Table 3). The whole results are presented in Supplementary Table 2. The results indicated plateau values $\left(\mathrm{N}_{\max }\right.$ or $\mathrm{B}_{\max }$ values $)$ for adsorption about $1000-1200$ and $850-990 \mathrm{mgg}^{-1}$ dry cell walls in $0 \%$ and $15 \%$ ethanol, 
respectively. By contrast, Bindon et al. ${ }^{45}$ obtained $\mathrm{N}_{\max }$ values of $250 \mathrm{mgg}^{-1}$ for skin cell wall AISs. These authors also observed twice higher adsorption on pulps than on skin cell walls ${ }^{47}$. Our results are thus higher, but this may be related to the differences in the preparation method. In $15 \%$ ethanol, we obtained $\mathrm{K}_{\mathrm{d}}$ value between 1.9 and $2.2\left(\mathrm{gL}^{-1}\right)$ corresponding to a $\mathrm{K}_{\mathrm{L}}$ between 0.45-0.53 $\mathrm{Lg}^{-1}$ (Supplementary Table 2). This is 4 to 5 times higher than that found with a mDP11 tannin fraction and skin cell walls ${ }^{43}$. If we assume that there are two types of sites, for example sites richer in proteins and sites richer in polysaccharides, and we are only interested in the second $\mathrm{K}_{\mathrm{d}}$, which would be that of the polysaccharides, we find $\mathrm{K}_{\mathrm{d} 2} \sim 6$ at $15 \% \mathrm{EtOH}$. This would correspond to a $\mathrm{K}_{\mathrm{L}} \sim 0.16$, which is close to the values found by Bindon et al. $(0.10$ and 0.18$)^{43}$. However, when working with fresh material, Bindon et al. ${ }^{45}$ showed that the addition of fresh mesocarp obtained by washing the material with citric acid induced the adsorption of about $50 \%$ of the tannins initially present in solution, contrary to the results obtained on purified pulp cell walls but in agreement with our data.

\section{3-2 Anthocyanin adsorption by FWIM}

Results of adsorption experiments performed with anthocyanins at concentrations between 0.1 and $2 \mathrm{gL}^{-1}$ are shown in Figure 2. Anthocyanins exhibited only a very low affinity for FWIM (Figure 2A): the percentage of adsorbed anthocyanins from solution varied between 16 to $28 \%$, depending on the initial concentration in the solution (Table 1). No differences were observed between the two varieties and the deg+ and deg- modalities, and ethanol content had no impact. Higher reversibility was evidenced for anthocyanins compared to tannins, (Figure 2B), likely in relation to their monomeric nature. This reversibility was influenced by the variety (higher for Grenache than for Carignan) and was strongly decreased in the presence of $15 \%$ ethanol, especially at high concentrations.

Anthocyanins in the fraction extracted from skins were mainly non-acylated glycosylated anthocyanins (93\%) and the second most abundant population were $p$ - 
coumaroylated anthocyanins (5\%) (Figure 2C). Other acylated anthocyanins only represented a very minor proportion of the fraction. Analysis showed a marked selectivity for the adsorption of $p$-coumaroylated derivatives, and lower reversibility of their adsorption by comparison to non-acylated anthocyanins. This preferential adsorption of $p$-coumaroylated anthocyanins by FWIM is in line with the previous observations that they are only very little extracted by diffusion or during winemaking compared to their initial content in skins ${ }^{3,5}$. Present results suggest that their preferential adsorption on both skin and flesh has the same cause. Although no significant impact of ethanol was observed here on anthocyanin adsorption, its impact on reversibility might be related to lower solubility of $p$-coumaroylated anthocyanins in $15 \%$ than in $0 \%$ ethanol.

\section{3-3 Interactions of tannins and anthocyanins mixtures}

In this set of experiments, adsorption was studied for mixtures of anthocyanins and tannins at different concentrations and ratios. The HPSEC chromatograms of the initial solution, adsorbed, and desorbed polyphenols are represented in Figure $3 \mathrm{~A}$ and $\mathrm{B}$ for a tannin concentration of $4 \mathrm{gL}^{-1}$ in the presence of 0.5 and $2 \mathrm{gL}^{-1}$ anthocyanins. As results were very similar for Grenache and Carignan FWIM, only the results of the Grenache are shown here. The whole result are represented in Figure 3C. In these conditions and in agreement with previous work ${ }^{43}$, anthocyanins did not impact tannin adsorption. This does not necessarily reflect a lack of competition between anthocyanins and tannins for potential binding sites. Indeed, monomers are easily desorbed when they do not present a very high affinity for a binding site whereas, with polymers like tannins, which usually possess several binding sites, desorption is unlikely to occur simultaneously for all sites. In our experimental conditions, the presence of anthocyanins also had a minor impact on the reversibility of the adsorption of tannins (Figure 3C). 
The impact of tannins on anthocyanin adsorption was studied in $15 \%$ ethanol for 0.5 and $2 \mathrm{gL}^{-1}$ concentration of anthocyanins and four different tannin concentrations (Figure 4). At usual anthocyanin concentrations in wines $\left(0.5 \mathrm{gL}^{-1}\right)$, the presence of tannins at low concentration $\left(0.5 \mathrm{gL}^{-1}\right)$ induced a decrease in anthocyanin adsorption but this impact diminished as the tannin concentration increased and was no more visible at $4 \mathrm{gL}^{-1}$. At high anthocyanin concentrations $\left(2 \mathrm{gL}^{-1}\right)$, a decrease of anthocyanin adsorption and enhanced reversibility were observed whatever the tannin concentration. This decrease varied between 27 and 33\% for the Carignan FWIM and between 13 and 15\% for the Grenache ones, with no impact of the sugar content of the berries. Results obtained at $2 \mathrm{gL}^{-1}$ anthocyanins thus tend to indicate a competition between anthocyanins and tannins for interaction sites on the FWIM. However, this does not explain the results obtained at low anthocyanin contents and the decreasing impact of tannins as their concentration increases. A hypothesis could be anthocyanin-tannin and anthocyanin-anthocyanin interactions. At low anthocyanin concentration, their enhanced adsorption by FWIM when the tannin concentration increases could be related to interactions between anthocyanins and adsorbed tannins. At high anthocyanin concentrations, competition between anthocyanin-anthocyanin interactions (copigmentation) and anthocyanin-adsorbed tannin interactions may perhaps reduce the latter.

In previous experiments, Bindon et al. ${ }^{43}$ observed that the adsorption of anthocyanins by cell walls increased in the presence of tannins $\left(1.25 \mathrm{gL}^{-1}\right.$ tannins $)$ for initial concentrations of anthocyanins between 0 and $5 \mathrm{gL}^{-1}$, and then decreased at higher initial anthocyanin contents. These results can be compared to those obtained in the present study for tannin concentrations of 1 and $2 \mathrm{gL}^{-1}$ and anthocyanin concentrations of 0.5 and $2 \mathrm{gL}^{-1}$. In all cases, we observed a decrease and not an increase in anthocyanin adsorption. Measurements in this previous work were done after 1 hour of contact, whereas we waited 30 hours. When we performed kinetics experiments, we pointed out that tannin adsorption takes time. The exchange between 
anthocyanins and tannin at the interaction sites is probably a time-dependent phenomenon and probably explains the differences in results.

\section{3-4 Characterization of flesh cell walls}

The dry weight of the purified flesh cell wall AIS, along with their global composition in neutral sugars, acidic sugars, and amino acids are given in Table 3. Statistical analyses of their sugar composition did not show significant differences between the two varieties and the two maturities. On the contrary, the total amount of amino acids differed between deg + and deg- modalities, the deg- modality being richer in total amino acids. In addition, the Grenache deg+ modality was richer than the Carignan one. The proportions of several amino acids, in particular hydroxyproline, proline, aspartic acid, methionine, phenylalanine, and serine differed significantly in Carignan and Grenache.

The composition of the carbohydrates of the flesh cell walls was analysed using the Comprehensive Microarray Polymer Profiling (CoMPP) method ${ }^{19,26,48}$. The extracts resulting from sequential extraction using CDTA (pectin rich fraction) and $\mathrm{NaOH}$ (hemicellulose rich fraction) were probed with $28 \mathrm{mAbs}$ or CBMs. These antibodies were chosen as they recognize a broad range of different cell wall polymers. The CDTA fraction includes pectic polysaccharides (homogalacturonans HG, rhamnogalacturonans RGI, and its side chains : arabinans, galactans and arabinogalactans), Arabinogalactan-Proteins, and extensins. The $\mathrm{NaOH}$ fraction is rich in hemicellulosic polysaccharides (mannans, glucan/xyloglucan, xylans), and cellulose (Figure 5). RGII was not studied, as there is no monoclonal antibody for detecting this polymer. HG epitopes in samples were recognized by mAbs JIM5, JIM7, LM18, LM19, LM20, 2F4 and PAM1/ RGI by mAbs INRA-RU1 and INRA-RU2/ and its side chains by mAbs LM5, LM6, LM13/ mannans by mAb LM21, xyloglucan by mAbs LM8, LM15, LM24 and LM25/ cellulose by CBM3a/ extensins by mAbs LM1, JIM11, JIM20 and AGPs by mAbs JIM8, JIM13, LM14 and LM2. 
In the pectin-rich fraction, the mAb JIM7 and LM20 showed the highest signal intensity compared with the other HG antibodies used, confirming the previous findings that grape berry pectins are highly methyl esterified ${ }^{49}$. Both mAb JIM7 and LM20 recognize methyl-esterified HG polymers but do not bind to un-esterified HG. Weaker signals were observed for mAbs JIM5, LM18, and LM19. This indicated the presence of demethyl-esterified HG zones, but in lower amounts than esterified HG. Similar signals were found for the mAbs JIM5 and JIM7 in the two varieties. The JIM7/JIM5 ratio showed that there are about 4 times less de-esterified HG than esterified HG in their flesh cell walls. The pectin-rich fraction of the flesh cell wall for the two varieties do not seem to contain a blockwise of desesterified HG (mAbs PAM1).

In addition to polysaccharides of the RG family (Backbone of rhamnogalacturonan I (INRA-RU1 and INRA-RU2), the arabinan epitopes, recognized by mAbs LM6 and mAbs LM13 antibodies, were present in the flesh cell walls contrary to the galactan epitope recognized by mAbs LM5 antibodies. The signal of arabinan (attached as side chains of RGI) was found to be higher in Carignan varieties compared to Grenache (significantly higher according to the factorial and one-way ANOVA). The RGI and RGI side-chain epitopes were extracted not only with CDTA but also with $\mathrm{NaOH}$, and in higher proportions for the Carignan than for the Grenache flesh cell walls (Figure 5a). This suggests that an RGI like structure is strongly associated with xyloglucan and cellulose microfibrils in the cell wall structure.

As expected, still in the pectic fraction, no polymer belonging to the mannan, glucan / xyloglucan, xylan, and cellulose family were detected, except for the mAb LM25, which recognises unsubstituted xyloglucan. Finally, differences were observed with the signals of probes for extensin (mAbs LM1, JIM11 and JIM20) and AGP (mAbs LM2, LM14, JIM8, and JIM13) epitopes in the CDTA fraction. Extensins define a subgroup of the hydroxyproline rich glycoprotein (HRGP) superfamily and incorporate characteristic $\beta$-L-arabinofuranoside repetitive glycosylation motifs. AGPs (arabinogalactan proteins) are rich in hydroxyproline but 
also in serine. The ANOVA showed significant differences between varieties with the JIM11 and the JIM20 extensin antibodies. Extensins play an important structuring role in the assembly of plant cell walls, ${ }^{50-52}$, but also in plant defence ${ }^{53}$. Extensins were also detected in the $\mathrm{NaOH}$ fraction, but mainly with the Grenache variety, indicating a different localization or associations with other polymers for the two varieties. Higher AGPs contents were found in the Grenache flesh cell wall CDTA fractions than in the Carignan ones, which is consistent with the differences observed in amino acids composition (higher proportions of hydroxyproline in Grenache than in Carignan and serine in Carignan than in Grenache).

In the hemicellulosic rich fraction ( $\mathrm{NaOH}$ Fraction), the samples were mainly recognized by the mAbs/CBMs for RGI side chains (INRA-RU1, INRA-RU2, LM6, and LM13), mannan (LM21) xyloglucan/glucan (LM15, LM25), and cellulose (CBM3a). The main hemicellulose polymers were xyloglucans, which consist of a backbone of $\beta-1,4-$ linked glucan where 3 out of

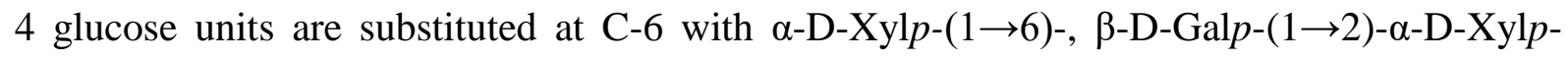
$(1 \rightarrow 6)$-, or $\alpha$-L-Fucp-( $1 \rightarrow 2)-\beta$-D-Gal $p-(1 \rightarrow 2)-\alpha-\mathrm{D}-\mathrm{Xyl} p$ - $(1 \rightarrow 6)$-side chains. Previous XGs isolated from mesocarp and exocarp cell walls of Grenache grape berries account for $8 \%$ of the walls from grape berries, and are composed of seven similar types of oligosacharides: XXXG, XLXG, XXLG, XLLG, XXFG, XLFG, XFFG and XXG ${ }^{54}$. No significant differences between samples were evidenced for these polysaccharides in this study.

The analysis of CoMPPs of the CDTA and $\mathrm{NaOH}$ fractions by PCA (Figure $5 \mathrm{~b}$ and $\mathrm{c}$ ) showed us that the parameter with the greatest impact was variety, particularly on de-esterified HG, hemicellulose, extensin, and arabinan compositions. This is in agreement with the adsorption data: the effect of variety is higher than the effect of maturity. Higher composition in extensins and RGI for Carignan are consistent with higher retention of tannins ${ }^{55}$, and thus higher adsorption in our experiments. Differences in composition were also observed with the partially methyl esterified homogalacturonan (mAbs LM19 and LM20). Watrelot et al. ${ }^{44}$ 
observed a positive impact of the degree of methylation of $\mathrm{HG}$ on their interactions with tannins in solution, but only with very different $\mathrm{HG}(0,30$, and $70 \%$ of methylation $)$ and with relatively high molecular weight tannins (mDP30). They could not detect interactions between mDP9 tannins and homogalacturonans. The tannins used in our experiments were extracted in winelike conditions and have a mDP around 9. This suggests that differences in homogalacturonans are not responsible for the differences observed here in adsorption.

In previous studies, a positive correlation was observed between the cellulose content and the degree of methylation of pectins and anthocyanin extraction ${ }^{56}$. In our study, it was difficult to link the adsorption of anthocyanins to the structural composition of the flesh cell walls since this adsorption was very low and that only minor differences were observed between the two varieties and the two different sugar contents of the berries.

\section{4- Conclusion}

The flesh cell wall materials have the potential to alter the composition of polyphenols in solution through the adsorption of tannins and anthocyanins The adsorption isotherms did not show a high affinity of the tannins for most of the interaction sites present in the FWIMs but underlined the high adsorption capacity of the latter: no plateau could be reached even for concentrations as high as $8 \mathrm{gL}^{-1}$. In the present study and in agreement with a previous work ${ }^{45}$, we found that at their usual concentration in wines, more than half of the tannins were adsorbed by FWIM and eliminated from the solution. In an earlier study, we found that at a final ethanol concentration of $15 \%$, about $20 \%$ of the polymeric tannins diffuse from the skin to the wine for the two studied varieties, leading to final concentrations in solution between 0.6 and $0.8 \mathrm{~g} / \mathrm{L}$. If $50 \%$ are adsorbed by FWIM, this would lead to final concentrations in wines of about $0.3-0.4$ $\mathrm{g} / \mathrm{L}$. Although higher temperatures than those applied here may increase the diffusion of tannins 
from the skins in red winemaking and decrease their interactions, this seems quite low and raises two questions: the role played by seeds, which are another important source of polymeric tannins in the grappe; the impact of adsorption/interaction phenomena on the equilibrium between solid and liquid phase involved in the diffusion of tannins from the skins as well as the seeds ${ }^{4}$. These questions will be addressed in a further work.

Unlike tannins, anthocyanins have very low affinity for FWIM and the amount of anthocyanins bound remains very small even at high anthocyanin concentrations. Furthermore, the presence of tannins at their usual concentrations in red wines decreases this adsorption. This indicates that the presence of FWIM will not strongly affect their concentration in wines. They likely also do not strongly impact anthocyanin extraction during pressing for rosé wines. However and concerning anthocyanins, an important observation in the present work is the preferential adsorption of $p$-coumaroylated anthocyanins, even if the latter only represented a minor proportion of the initial anthocyanins in the polyphenolic extract used and in agreement with their lower extraction from skins during maceration ${ }^{5}$..

An impact of the variety on the interactions was highlighted. According to the CoMPP results, this higher interaction observed with Carignan variety can be related to the high interactions between tannins and the extensin and arabinan part of its flesh cell walls. The flesh of Carignan berries was able to adsorb roughly $20 \%$ more tannins than the flesh of Grenache.

\section{5- Acknowledgments}

This work was carried out as part of "Interfaces" flagship project, publicly funded through ANR (the French National Research Agency) under the "Investissements d'avenir" program with the reference ANR-10-LABX-001-01 Labex Agro and coordinated by Agropolis Fondation under the reference ID 1603-001. The authors would like to thank their colleagues from the Pech Rouge Experimental Unit for their help in harvesting and sorting the berries and 
their colleagues from the UMR SPO for their participation in the preparation of the samples. The authors would also like to thank M. John Moore and M. Brock Kuhlman from the Institute for Wine Biotechnology, Departement of Viticulture and Oenology, Stellenbosh University for their guidance and helpful discussions on the CoMPP method. 


\section{References}

1 Romero-Cascales I, Fernández-Fernández JI, López-Roca JM, and Gómez-Plaza E. The maceration process during winemaking extraction of anthocyanins from grape skins into wine. Eur Food Res Technol 221:163-167 (2005).

2 Hazak JC, Harbertson JF, Adams DO, Lin CH, and Ro BH. The phenolic components of grape berries in relation to wine composition. Acta Hortic 689:189-196 (2005).

3 Fournand D, Vicens A, Sidhoum L, Souquet JM, Moutounet M, and Cheynier V. Accumulation and extractability of grape skin tannins and anthocyanins at different advanced physiological stages. J Agric Food Chem 54:7331-7338 (2006).

4 Setford PC, Jeffery DW, Grbin PR, and Muhlack RA. Factors affecting extraction and evolution of phenolic compounds during red wine maceration and the role of process modelling. Trends Food Sci Technol; 69:106-117 (2017).

5 Abi-Habib E, Poncet-Legrand C, Roi S, Carrillo S, Doco T, and Vernhet A. Impact of grape variety, berry maturity and size on the extractability of skin polyphenols during model wine-like maceration experiments. J Sci Food Agric 101:3257-3269 (2021).

6 Fulcrand H, Dueñas M, Salas E, and Cheynier V. Phenolic reactions during winemaking and aging. Am J Enol Vitic 57:289-297 (2006).

7 Salas E, Fulcrand H, Meudec E, and Cheynier V. Reactions of Anthocyanins and Tannins in Model Solutions. J Agric Food Chem 51:7951-7961 (2003).

8 Mekoue Nguela J, Sieczkowski N, Roi S, and Vernhet A. Sorption of Grape Proanthocyanidins and Wine Polyphenols by Yeasts, Inactivated Yeasts, and Yeast Cell Walls. J Agric Food Chem 63:660-670 (2015).

9 Mekoue Nguela J, Poncet-Legrand C, Sieczkowski N, and Vernhet A. Interactions of Grape tannins and Wine Polyphenols with a Yeast Protein Extract, Mannoproteins and B-glucan. Food Chem; 210:671-682 (2016). 
10 Bindon KA, Li S, Kassara S, and Smith PA. Retention of Proanthocyanidin in Wine-like Solution Is Conferred by a Dynamic Interaction between Soluble and Insoluble Grape Cell Wall Components. J Agric Food Chem 64:8406-8419 (2016).

11 Bindon KA, Smith PA, and Kennedy JA. Interaction between Grape-Derived Proanthocyanidins and Cell Wall Material. 1. Effect on Proanthocyanidin Composition and Molecular Mass. J Agric Food Chem 58:2520-2528 (2010).

12 Bindon KA, Smith PA, Holt H, and Kennedy JA. Interaction between grape-derived proanthocyanidins and cell wall material. 2. implications for vinification. J Agric Food Chem 58:10736-10746 (2010).

13 Ruiz-Garcia Y, Smith PA, and Bindon KA. Selective extraction of polysaccharide affects the adsorption of proanthocyanidin by grape cell walls. Carbohydr Polym 114:102-114 (2014).

14 Vicens A, Fournand D, Williams P, Sidhoum L, Moutounet M, and Doco T. Changes in polysaccharide and protein composition of cell walls in grape berry skin (Cv. Shiraz) during ripening and over-ripening. J Agric Food Chem 57:2955-2960 (2009).

15 Ortega-Regules A, Ros-García JM, Bautista-Ortín AB, López-Roca JM, and GómezPlaza E. Differences in morphology and composition of skin and pulp cell walls from grapes (Vitis vinifera L.): Technological implications. Eur Food Res Technol 227:223$231(2008)$.

16 Bindon KA and Kennedy JA. Ripening-induced changes in grape skin proanthocyanidins modify their interaction with cell walls. J Agric Food Chem 59:2696-2707 (2011).

17 Segade SR, Giacosa S, Gerbi V, and Rolle L. Berry skin thickness as main texture parameter to predict anthocyanin extractability in winegrapes. LWT - Food Sci Technol; 44:392-398 (2011).

18 Kilmister RL, Mazza M, Baker NK, Faulkner P, and Downey MO. A role for 
anthocyanin in determining wine tannin concentration in Shiraz. Food Chem 152:475$482(2014)$.

19 Nguema-Ona E, Moore JP, Fagerström A, Fangel JU, Willats WGT, Hugo A, and Vivier MA. Profiling the main cell wall polysaccharides of tobacco leaves using highthroughput and fractionation techniques. Carbohydr Polym 88:939-949 (2012).

20 Apolinar-Valiente R, Romero-Cascales I, López-Roca JM, Gómez-Plaza E, and RosGarcía JM. Application and comparison of four selected procedures for the isolation of cell-wall material from the skin of grapes cv. Monastrell. Anal Chim Acta 660:206-210 (2010).

21 Saeman JF, Moore WE, Mitchell RL, and Millett MA. Techniques for the determination of pulp constituents by quantitiative paper chromatography. TAPPI 37(8):336-343 (1954).

22 Harris PJ, Henri RJ, Blakeney AB, and Stone BA. An improved method for the methylation analysis of oligosaccharides and polysaccharides. Carbohydr Res 55:205208 (1984).

23 Blumenkrantz N and Asboe-Hansen G. New method for Quantitative Determination of Uronic Acids. Anal Biochem 54(2):484-489 (1973).

24 Ahmed ERA and Labavitch JM. Method for accurate determination of cell wall. J Food Biochem 1:361-365 (1977).

25 Klavons JA and Bennett RD. Determination of Methanol Using Alcohol Oxidase and Its Application to Methyl Ester Content of Pectins. J Agric Food Chem 34:597-599 (1986).

26 Moore JP, Nguema-Ona E, Fangel JU, Willats WGT, Hugo A, and Vivier MA. Profiling the main cell wall polysaccharides of grapevine leaves using high-throughput and fractionation methods. Carbohydr Polym.; 99:190-198 (2014).

27 Zietsman AJ, Moore JP, Fangel JU, Willats WGT, Trygg J, and Vivier MA. Following 
the compositional changes of fresh grape skin cell walls during the fermentation process in the presence and absence of maceration enzymes. J Agric Food Chem 63:2798-2810 (2015).

28 Moller I, Sørensen I, Bernal AJ, Blaukopf C, Lee K, Øbro J, Pettolino F, Roberts A, Mikkelsen JD, Knox JP, Bacic A, and Willats WGT. High-throughput mapping of cellwall polymers within and between plants using novel microarrays. Plant J 50:1118-1128 (2007).

29 Dubois M, Gilles KA, Hamilton JK, Rebers PA, and Smith F. Colorimetric method for determination of sugars and related substances. Anal Chem 28:350-356 (1956).

30 Bradford M. A rapid and sensitive method for the quantitation of microgram quantities of protein utilizing the principle of protein-dye binding. Anal Biochem 72:248-254 (1976).

31 Langmuir I. The adsorption of gases on plane surfaces of glass, mica and platinum. $J A m$ Chem Soc 40:1361-1403 (1918).

32 Le Bourvellec C and Renard CMGC. Non-covalent interaction between procyanidins and apple cell wall material. Part II: Quantification and impact of cell wall drying. Biochim Biophys Acta - Gen Subj 1725:1-9 (2005).

33 Beaver JW, Medina-Plaza C, Miller K, Dokoozlian N, Ponangi R, Blair T, Block D, and Oberholster A. Effects of the Temperature and Ethanol on the Kinetics of Proanthocyanidin Adsorption in Model Wine Systems. J Agric Food Chem 68:28912899 (2020).

34 Le Bourvellec C , Guyot S, and Renard CMGC. Non-covalent interaction between procyanidins and apple cell wall material: Part I. Effect of some environmental parameters. Biochim Biophys Acta 1672:192-202 (2004).

35 Poncet-Legrand C, Cartalade D, Putaux J-L, Cheynier V, and Vernhet A. Flavan-3-ol 
aggregation in model ethanolic solutions: Incidence of polyphenol structure, concentration, ethanol content, and ionic strength. Langmuir 19:10563-10572 (2003). Cartalade D and Vernhet A. Polar interactions in flavan-3-ol adsorption on solid surfaces. J Agric Food Chem 54:3086-3094 (2006).

37 Le Bourvellec C, Bouchet B, and Renard CMGC. Non-covalent interaction between procyanidins and apple cell wall material. Part III: Study on model polysaccharides. Biochim Biophys Acta - Gen Subj 1725:10-18 (2005).

38 Le Bourvellec C, Watrelot A a, Ginies C, Imberty A, and Renard CMGC. Impact of processing on the noncovalent interactions between procyanidin and apple cell wall. $J$ Agric Food Chem 60:9484-9494 (2012).

39 Poncet-Legrand C, Gautier C, Cheynier V, and Imberty A. Interactions between Flavan3-ols and Poly(L-proline) Studied by Isothermal Titration Calorimetry: Effect of the Tannin Structure. J Agric Food Chem 55:9235-9240 (2007).

40 McRae JM, Falconer RJ, and Kennedy $\mathrm{J}$ a. Thermodynamics of grape and wine tannin interaction with polyproline: implications for red wine astringency. J Agric Food Chem 58:12510-12518 (2010).

41 Frazier RA, Deaville ER, Green RJ, Stringano E, Willoughby I, Plant J, and MuellerHarvey I. Interactions of tea tannins and condensed tannins with proteins. J Pharm Biomed Anal 51:490-495 (2010).

42 Le Bourvellec C and Renard CMGC. Non-covalent interaction between procyanidins and apple cell wall material. Part II: Quantification and impact of cell wall drying. Biochim Biophys Acta - Gen Subj 1725:1-9 (2005).

43 Bindon KA, Madani SH, Pendleton P, Smith PA, and Kennedy JA. Factors affecting skin tannin extractability in ripening grapes. J Agric Food Chem 62:1130-1141 (2014).

44 Watrelot A, Le Bourvellec C, Imberty A, and Renard CMGC. Interactions between 
pectic compounds and procyanidins are influenced by methylation degree and chain length. Biomacromolecules 14:709-718 (2013).

45 Bindon KA, Kassara S, and Smith PA. Towards a model of grape tannin extraction under wine-like conditions: the role of suspended mesocarp material and anthocyanin concentration. Aust J Grape Wine Res 23:22-32 (2017).

46 Bindon KA and Smith PA. Comparison of the affinity and selectivity of insoluble fibres and commercial proteins for wine proanthocyanidins. Food Chem; 136:917-928 (2013).

47 Bindon KA, Bacic A, and Kennedy JA. Tissue-specific and developmental modifications of grape cell walls influence the adsorption of proanthocyanidins. J Agric Food Chem 60:9249-9260 (2012).

48 Gao Y, Fangel JU, Willats WGT, Vivier MA, and Moore JP. Dissecting the polysaccharide-rich grape cell wall changes during winemaking using combined highthroughput and fractionation methods. Carbohydr Polym.; 133:567-577 (2015).

49 Gao Y, Zietsman AJJ, Vivier MA, and Moore JP. Deconstructing wine grape cell walls with enzymes during winemaking: New insights from glycan microarray technology. Molecules 24 (2019).

50 Cannon MC, Terneus K, Hall Q, Tan L, Wang Y, Wegenhart BL, Chen L, Lamport DTA, Chen Y, and Kieliszewski MJ. Self-assembly of the plant cell wall requires an extensin scaffold. Proc Natl Acad Sci U S A 105:2226-2231 (2008).

51 Lamport DTA, Kieliszewski MJ, Chen Y, and Cannon MC. Role of the Extensin Superfamily in Primary Cell Wall Architecture. Plant Physiol 156:11-19 (2011).

52 Chormova D and Fry SC. Boron bridging of rhamnogalacturonan-II is promoted in vitro by cationic chaperones, including polyhistidine and wall glycoproteins. New Phytol 209:241-251 (2016).

53 Castilleux R, Plancot B, Ropitaux M, Carreras A, Leprince J, Boulogne I, Follet-Gueye 
ML, Popper ZA, Driouich A, and Vicré M. Cell wall extensins in root-microbe interactions and root secretions. J Exp Bot 69:4235-4247 (2018).

54 Doco T, Williams P, Pauly M, O’Neill MA, and Pellerin P. Polysaccharides from grape berry cell walls. Part II. Structural characterization of the xyloglucan polysaccharides. Carbohydr Polym 53:253-261 (2003).

55 Gao Y, Fangel JU, Willats WGT, Vivier MA, and Moore JP. Dissecting the polysaccharide-rich grape cell wall matrix using recombinant pectinases during winemaking. Carbohydr Polym 152:510-519 (2016).

56 Ortega-Regules A, Romero-Cascales I, Ros-García JM, López-Roca JM, and GómezPlaza E. A first approach towards the relationship between grape skin cell-wall composition and anthocyanin extractability. Anal Chim Acta 563:26-32 (2006).

Tables 


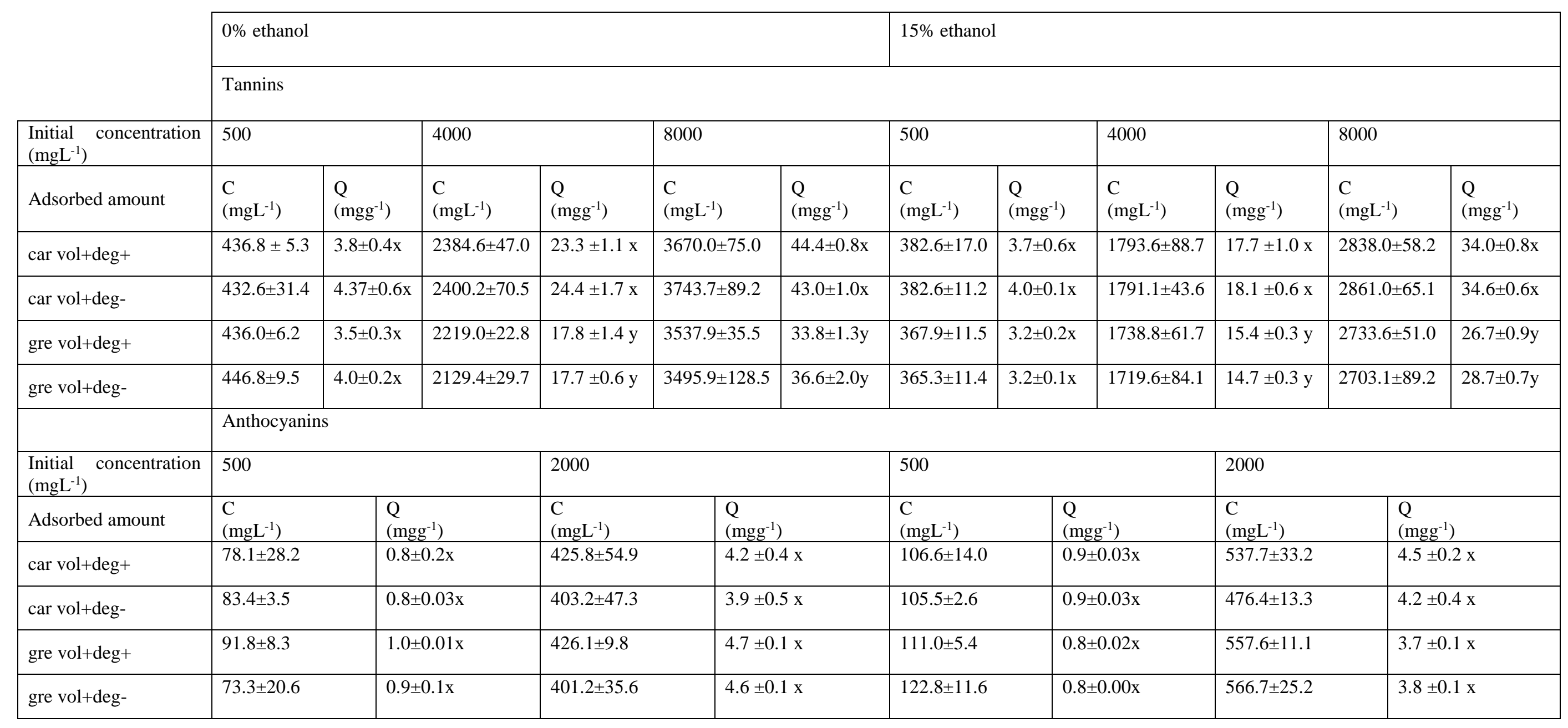

Table 1. Adsorbed tannin and anthocyanin amounts expressed in Concentration $\left(\mathrm{mgL}^{-1}\right)$ and Quantity $\left(\mathrm{mg} \mathrm{g}^{-1}\right.$ fresh flesh water-insoluble materials) for Carignan and Grenache, in 0 and $15 \%$ of ethanol model solutions. Different letters indicate significant differences between samples for a given parameter (One-way ANOVA followed by Tukey's test for $\mathrm{p}<0.05$ ) 
Table 2. Parameters derived from one-site and two-site saturation binding curve fitting, corresponding to the experimental results plotted in Figure 1A.

\begin{tabular}{|c|c|c|c|c|c|c|c|c|}
\hline & \multicolumn{3}{|c|}{$\begin{array}{c}\text { One-site saturation } \\
\text { binding }\end{array}$} & \multicolumn{5}{|c|}{ Two-site saturation binding } \\
\hline & $\begin{array}{c}\mathrm{B}_{\max } \\
\text { (mg tannin / } \\
\text { of flesh) } \\
\end{array}$ & $\begin{array}{l}K_{d} \\
g / L\end{array}$ & $\begin{array}{c}\text { Adj } \\
\mathrm{R}^{2} \\
\end{array}$ & $\begin{array}{c}\mathrm{B}_{\max 1} \\
\text { (mg tannin / } \mathrm{g} \\
\text { of flesh) } \\
\end{array}$ & $\begin{array}{c}\mathrm{K}_{\mathrm{d} 1} \\
\mathrm{~g} / \mathrm{L} \\
\end{array}$ & $\begin{array}{c}\mathrm{B}_{\max 2} \\
\text { (mg tannin / } \mathrm{g} \\
\text { of flesh) } \\
\end{array}$ & $\begin{array}{c}\mathrm{K}_{\mathrm{d} 2} \\
\mathrm{~g} / \mathrm{L}\end{array}$ & $\begin{array}{c}\text { Adj } \\
\mathrm{R}^{2} \\
\end{array}$ \\
\hline Car Deg+ 0\% & 76.21 & 3.45 & 0.976 & 6.548 & 0.030 & 177.9 & 16.3 & 0.998 \\
\hline Car Deg- 0\% & 61.65 & 2.08 & 0.978 & 7.597 & 0.046 & 98.3 & 7.54 & 0.999 \\
\hline Gre Deg+ $0 \%$ & 55.55 & 3.07 & 0.975 & 5.739 & 0.060 & 116.3 & 13.8 & 0.995 \\
\hline Gre Deg- 0\% & 72.66 & 4.66 & 0.965 & 5.547 & 0.028 & 369.0 & 48.5 & 0.992 \\
\hline Car Deg+ $15 \%$ & 60.80 & 4.48 & 0.979 & 5.821 & 0.096 & 200.5 & 32.0 & 0.999 \\
\hline Car Deg- $15 \%$ & 57.47 & 3.75 & 0.971 & 6.367 & 0.075 & 164.7 & 24.9 & 0.997 \\
\hline Gre Deg+ $15 \%$ & 42.36 & 3.21 & 0.975 & 3.390 & 0.042 & 58.14 & 7.71 & 0.996 \\
\hline Gre Deg- $15 \%$ & 53.47 & 4.87 & 0.978 & 3.900 & 0.039 & 122.1 & 20.8 & 0.999 \\
\hline
\end{tabular}


Table 3. Alcohol Insoluble Solids contents (AIS) and their composition in total sugars (neutral and acidic), amino acids and their relative amounts in the four modalities of Carignan and Grenache initial flesh. Different letters indicate significant differences between samples for a given concentration or relative amount (Tukey's test for $\mathrm{p}<0.05$ ).

\begin{tabular}{|c|c|c|c|c|c|}
\hline & & \multicolumn{2}{|c|}{ Carignan } & \multicolumn{2}{|c|}{ Grenache } \\
\hline & & Deg+ & Deg- & Deg+ & Deg- \\
\hline $\begin{array}{l}\text { AIS mgg-1 } \\
\text { fresh flesh }\end{array}$ & & $4.1 \pm 0.5 \mathrm{a}$ & $3.7 \pm 0.2 \mathrm{a}$ & $3.7 \pm 0.5 \mathrm{a}$ & $3.4 \pm 0.2 \mathrm{a}$ \\
\hline \multirow{2}{*}{$\begin{array}{l}\text { Total sugars } \\
\text { mgg-1 AIS }\end{array}$} & $\begin{array}{c}\text { Total neutral } \\
\text { sugars }\end{array}$ & $181.1 \pm 12.0 \mathrm{ab}$ & $199.4 \pm 6.9 \mathrm{ab}$ & $161.1 \pm 23.6 \mathrm{~b}$ & $218.9 \pm 22.4 \mathrm{a}$ \\
\hline & $\begin{array}{c}\text { Total acidic } \\
\text { sugars }\end{array}$ & $147.6 \pm 15.4 \mathrm{a}$ & $159.5 \pm 31.4 \mathrm{a}$ & $138.9 \pm 21.1 \mathrm{a}$ & $132.2 \pm 16.7 \mathrm{a}$ \\
\hline $\begin{array}{l}\text { Total amino } \\
\text { acids } \\
\text { mgg-1 AIS }\end{array}$ & & $218.9 \pm 7.0 \mathrm{c}$ & $255.9 \pm 3.4 \mathrm{a}$ & $238.4 \pm 5.2 \mathrm{~b}$ & $263.8 \pm 0.9$ a \\
\hline \multirow{7}{*}{$\begin{array}{c}\text { Relative } \\
\text { amounts of } \\
\text { sugars }(\%)\end{array}$} & Rhamnose & $4.82 \mathrm{a}$ & $4.68 \mathrm{a}$ & $5.57 \mathrm{a}$ & $4.60 \mathrm{a}$ \\
\hline & Fucose & $0.90 \mathrm{a}$ & $0.92 \mathrm{a}$ & $0.90 \mathrm{a}$ & $0.96 \mathrm{a}$ \\
\hline & Arabinose & $13.07 \mathrm{a}$ & $12.50 \mathrm{a}$ & $11.98 \mathrm{a}$ & $12.92 \mathrm{a}$ \\
\hline & Xylose & $8.85 \mathrm{a}$ & $6.67 \mathrm{a}$ & $6.14 \mathrm{a}$ & $5.69 \mathrm{a}$ \\
\hline & Mannose & $4.18 \mathrm{a}$ & $4.34 \mathrm{a}$ & $3.68 \mathrm{a}$ & $3.70 \mathrm{a}$ \\
\hline & Galactose & $11.92 \mathrm{a}$ & $12.01 \mathrm{a}$ & $12.05 \mathrm{a}$ & $11.63 \mathrm{a}$ \\
\hline & Glucose & $56.26 \mathrm{a}$ & $58.88 \mathrm{a}$ & $59.68 \mathrm{a}$ & $60.50 \mathrm{a}$ \\
\hline \multirow{20}{*}{$\begin{array}{c}\text { Relative } \\
\text { amounts of } \\
\text { amino acids } \\
(\%)\end{array}$} & Hydroxyproline & 3.00 b & $3.02 \mathrm{~b}$ & $3.53 \mathrm{a}$ & $3.51 \mathrm{a}$ \\
\hline & Proline & $5.67 \mathrm{~b}$ & $5.74 \mathrm{~b}$ & $6.17 \mathrm{a}$ & $6.43 \mathrm{a}$ \\
\hline & Alanine & $5.31 \mathrm{a}$ & $5.33 \mathrm{a}$ & $5.14 \mathrm{a}$ & $5.19 \mathrm{a}$ \\
\hline & Arginine & $4.88 \mathrm{a}$ & $4.86 \mathrm{a}$ & $5.04 \mathrm{a}$ & $5.36 \mathrm{a}$ \\
\hline & Aspartic acid & $9.53 \mathrm{a}$ & $9.64 \mathrm{a}$ & $8.88 \mathrm{~b}$ & $8.87 \mathrm{~b}$ \\
\hline & Cystine & $0.62 \mathrm{a}$ & $0.32 \mathrm{a}$ & $0.28 \mathrm{a}$ & $0.20 \mathrm{a}$ \\
\hline & Cysteic acid & $0.14 \mathrm{a}$ & $0.35 \mathrm{a}$ & $0.08 \mathrm{a}$ & $0.15 \mathrm{a}$ \\
\hline & Glutamic acid & $12.34 \mathrm{a}$ & $12.47 \mathrm{a}$ & $12.80 \mathrm{a}$ & $12.89 \mathrm{a}$ \\
\hline & Glycine & $5.45 \mathrm{a}$ & $5.16 \mathrm{~b}$ & 5.39 a & 5.39 a \\
\hline & Histidine & $4.07 \mathrm{a}$ & $4.40 \mathrm{a}$ & $4.62 \mathrm{a}$ & $3.35 \mathrm{a}$ \\
\hline & Isoleucine & $4.92 \mathrm{a}$ & $5.01 \mathrm{a}$ & $4.96 \mathrm{a}$ & $5.25 \mathrm{a}$ \\
\hline & Leucine & $7.17 \mathrm{a}$ & $6.81 \mathrm{~b}$ & $7.16 \mathrm{a}$ & $7.09 \mathrm{a}$ \\
\hline & Lysine & $8.44 \mathrm{a}$ & $8.21 \mathrm{a}$ & $8.45 \mathrm{a}$ & $8.22 \mathrm{a}$ \\
\hline & Methionine & 0.57 b & $0.57 \mathrm{~b}$ & 0.88 a & $1.03 \mathrm{a}$ \\
\hline & $\begin{array}{c}\text { Methionine } \\
\text { sulfone }\end{array}$ & $0.10 \mathrm{a}$ & $0.15 \mathrm{a}$ & $0.08 \mathrm{a}$ & $0.06 \mathrm{a}$ \\
\hline & Phenylalanine & $5.37 \mathrm{a}$ & $5.40 \mathrm{a}$ & $5.15 \mathrm{~b}$ & $5.10 \mathrm{~b}$ \\
\hline & Serine & $5.57 \mathrm{a}$ & $5.67 \mathrm{a}$ & $5.27 \mathrm{~b}$ & $5.21 \mathrm{~b}$ \\
\hline & Threonine & $5.24 \mathrm{ab}$ & $5.32 \mathrm{a}$ & $5.28 \mathrm{ab}$ & $5.14 \mathrm{~b}$ \\
\hline & Tyrosine & $3.86 \mathrm{a}$ & $3.36 \mathrm{a}$ & $3.14 \mathrm{a}$ & $2.26 \mathrm{a}$ \\
\hline & Valine & $6.07 \mathrm{a}$ & 6.23 & $6.06 \mathrm{a}$ & $6.16 \mathrm{a}$ \\
\hline
\end{tabular}




\section{Figures}
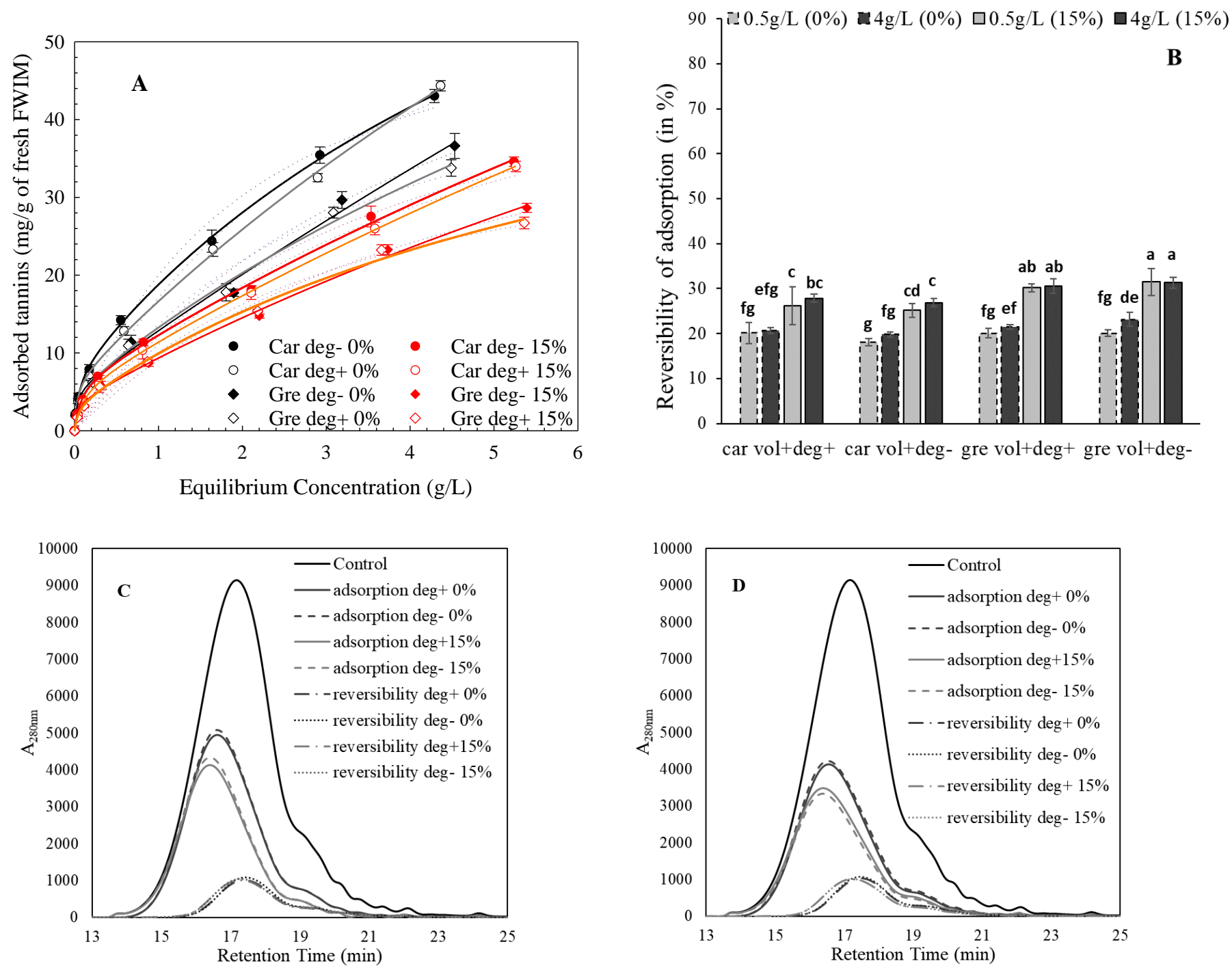

Figure 1. Adsorption isotherms of grape skin tannins (A) on the fresh Flesh Water Insoluble Material (FWIM) of Carignan and Grenache, at two different percentages of sugar (deg+; deg-) and in 0 and 15\% ethanol model solutions. Results are expressed in mg adsorbed tannins/g of fresh FWIM. Dotted lines are the fits obtained with a ligand saturation model (one site), solid lines the fits obtained with a twosite saturation model.(B) Reversibility of the adsorption. HPSEC analysis performed for a $4 \mathrm{gL}^{-1}$ initial tannin concentration in the solution for the two Carignan (C) and Grenache (D) deg+ and deg-modalities and the two ethanol concentrations ( 0 and $15 \%$ ) showing the size distribution of the tannins in the initial solution, the adsorbed tannins (obtained by subtracting the chromatogram of the supernatant after interaction from that of the initial solution) and the desorbed tannins (from reversibility experiments). 

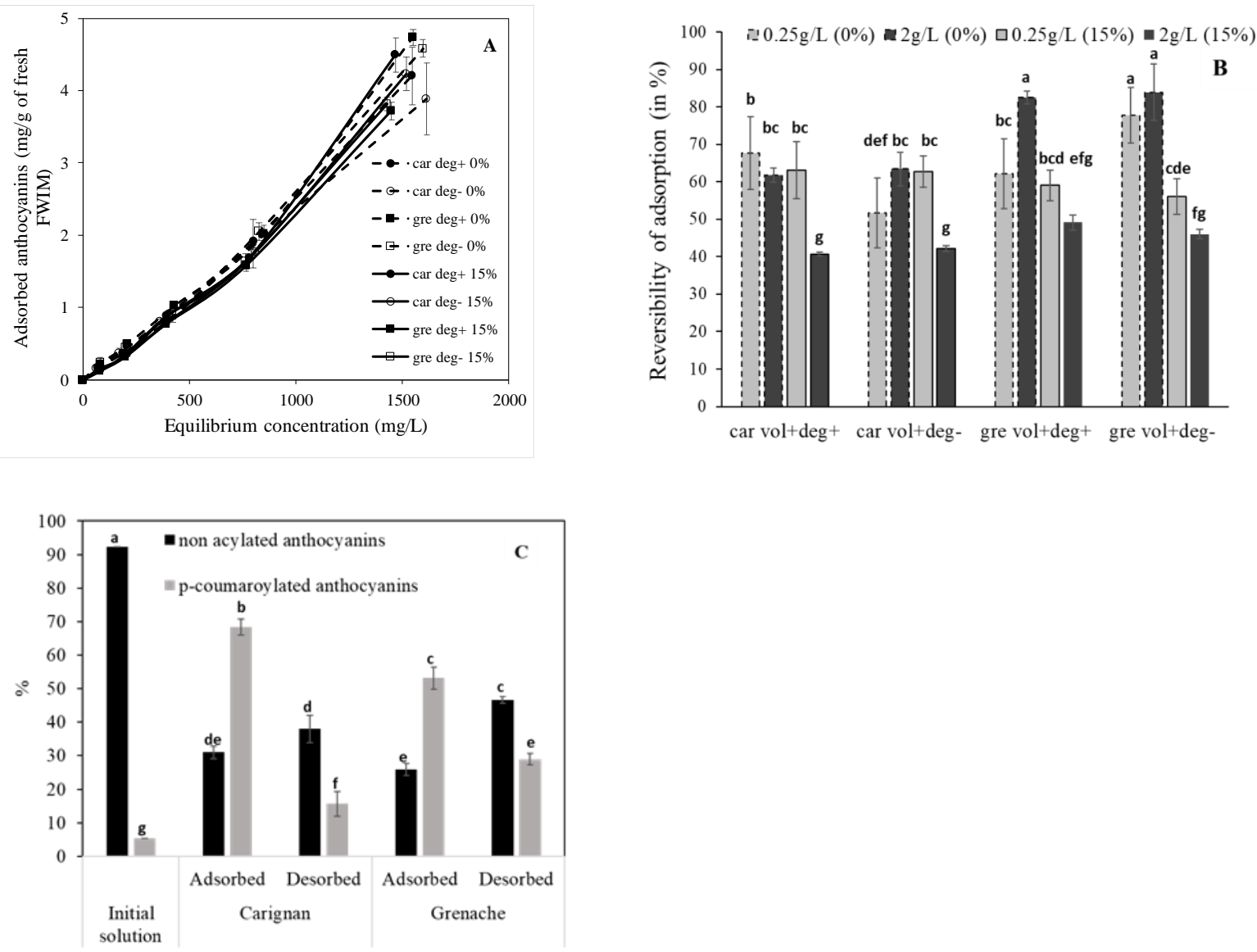

Figure 2. Adsorption isotherms of Anthocyanins (A) on the fresh Flesh Water Insoluble Material (FWIM) of Carignan and Grenache, at two different percentages of sugar (deg+; deg-) and in 0 and 15\% ethanol model solutions. Results are expressed in mg adsorbed anthocyanins/g of fresh FWIM. (B) Reversibility of the adsorption. (C) Proportions of $p$-coumaroylated and non-acylated anthocyanins in the initial anthocyanins fractions and of the adsorbed and desorbed (reversibility) anthocyanins (initial concentration in solution: $2 \mathrm{gL}^{-1}, 15 \%$ ethanol). 

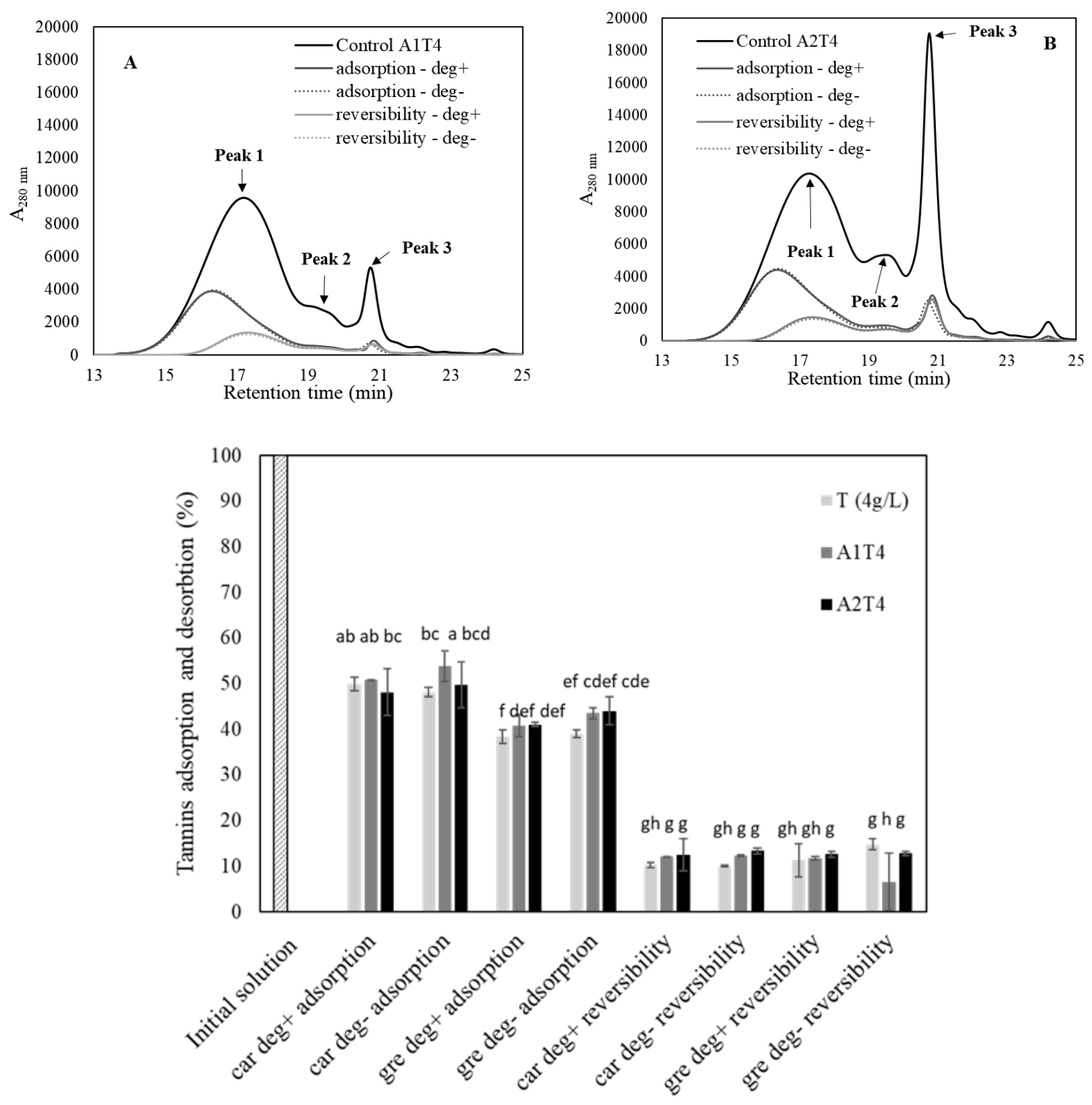

Figure 3. A) and B) High Performance Size Exclusion Chromatography (HPSEC) analysis showing the molecular size distribution of tannins and anthocyanins in the initial solutions (A1T4 and A2T4), adsorbed polyphenols after interactions with Grenache fresh Flesh Water Insoluble Material (FWIM), and reversibility of adsorbed polyphenols. Interaction experiments were performed in a $15 \%$ ethanol model solution. A1T4: initial anthocyanin and tannin concentrations of 0.5 and $4 \mathrm{gL}^{-1}$, respectively; A2T4: initial anthocyanin and tannin concentrations of 2 and $4 \mathrm{gL}^{-1}$, respectively. C) Percentage of adsorbed tannins and reversibility of the adsorption, 

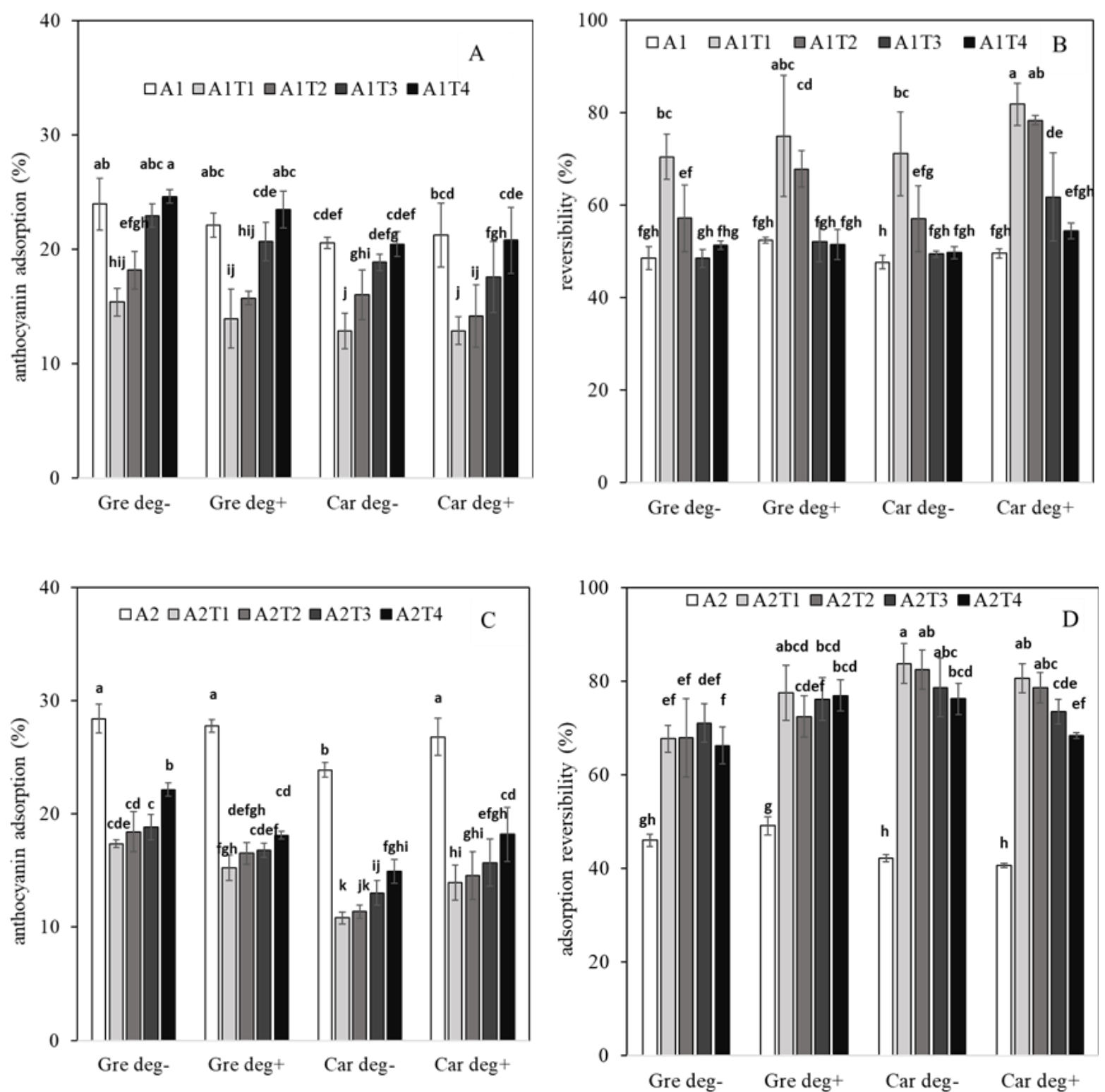

Figure 4. Adsorption and desorption of anthocyanins in the presence of different tannin concentrations in solution: $\mathrm{T} 1: 0.5 \mathrm{gL}^{-1}, \mathrm{~T} 2: 1 \mathrm{gL}^{-1}, \mathrm{~T} 3: 2 \mathrm{gL}-1$ and $\mathrm{T} 4: 4 \mathrm{gL}^{-1}$. A1 corresponds to a concentration in anthocyanins of $0.5 \mathrm{gL}^{-1}, \mathrm{~A} 2$ corresponds to $2 \mathrm{gL}^{-1}$. Graphs A) and C): percentage of adsorbed anthocyanins. B) and D): percentage of anthocyanins that are desorbed. Values were obtained from Total Red Pigments (TRP) measurements. Experiments were performed in the 15\% ethanol model solution. 


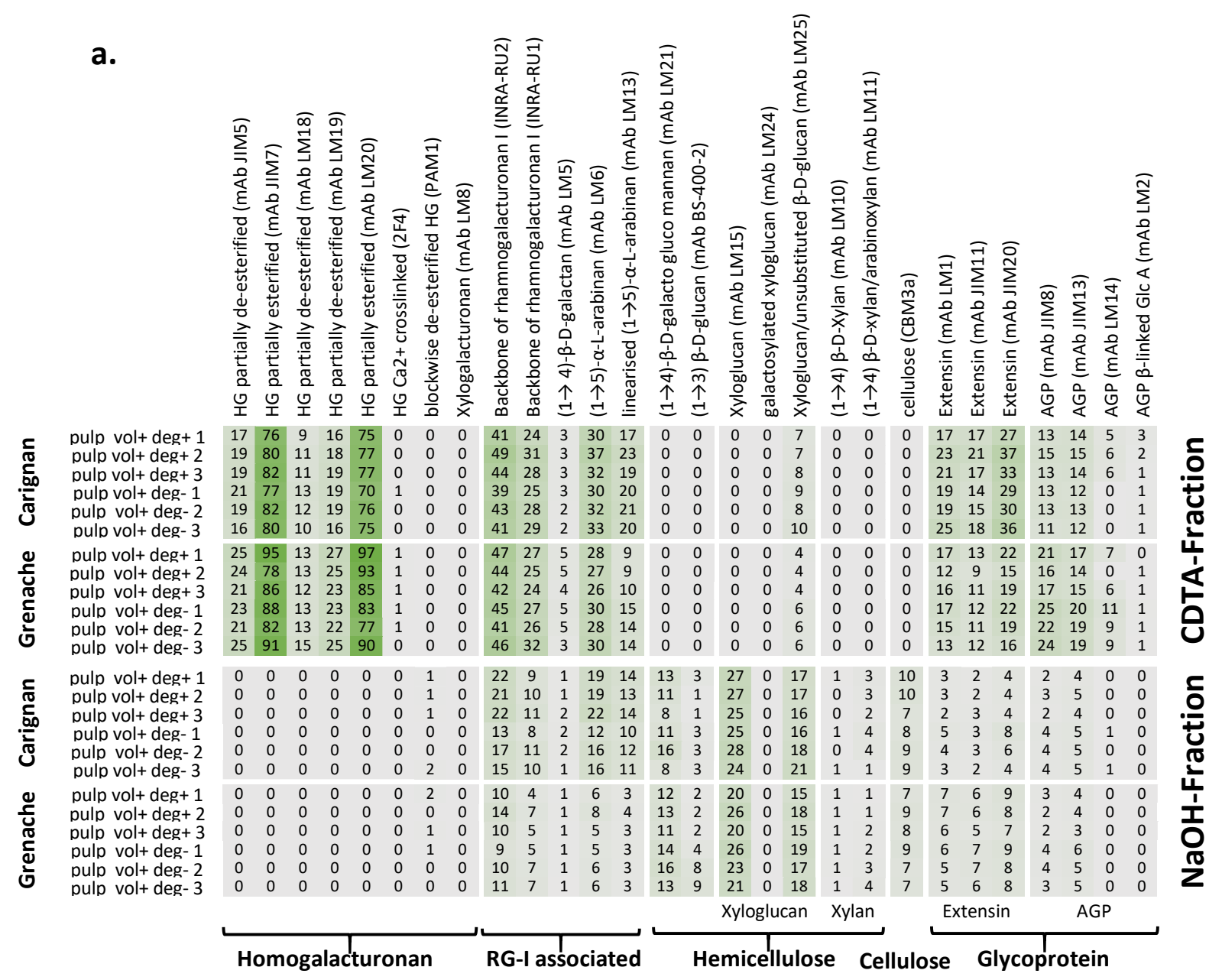

\section{b. CDTA-fraction}

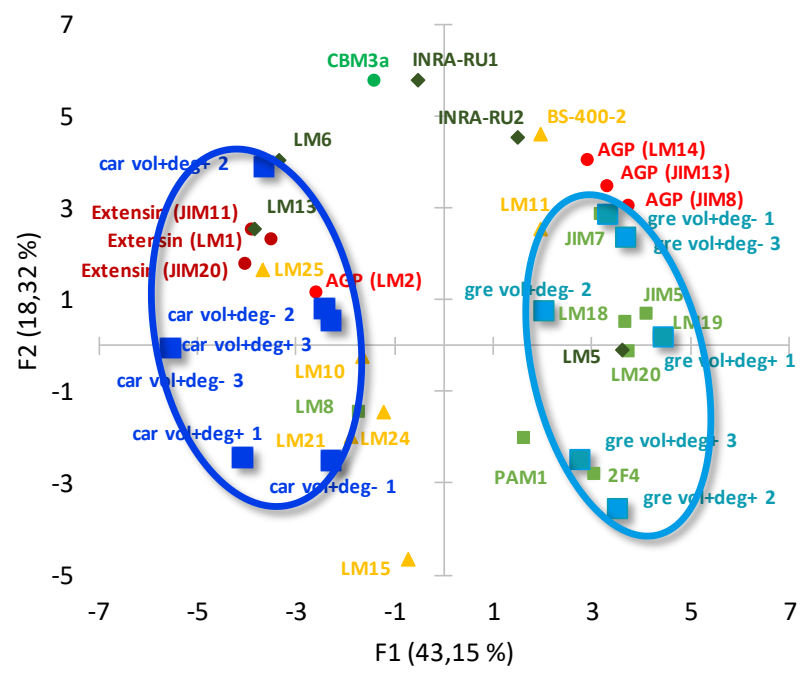

\section{c. $\mathrm{NaOH}$-fraction}

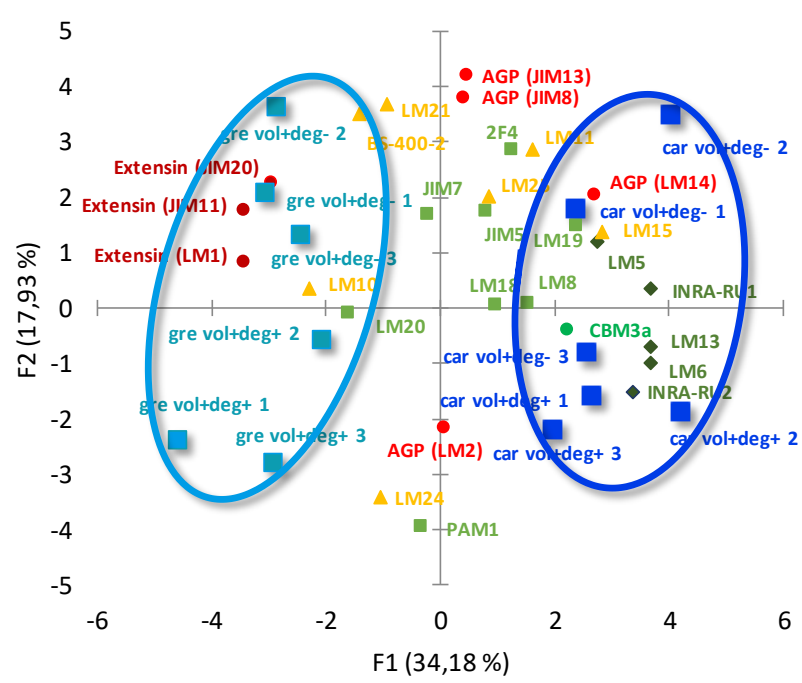

Figure 5. Comprehensive microarray polymer profiling (CoMPP) heatmap (a) showing cell wall polysaccharides and glycoproteins relative abundance using antibodies signal intensity reads on the CDTA (pectin-rich) and $\mathrm{NaOH}$ (hemicellulose-rich) fractions extracted from the Alcohol Insoluble Solids flesh of Carignan and Grenache varieties. A cut-off of 5 was applied to the raw data. (b): Principal Component Analysis (PCA) of the pectin-rich fraction (CDTA) and (c): PCA of the hemicellulose-rich fraction $(\mathrm{NaOH})$. On the PCA, samples (-Carignan and - Grenache) are coloured according to their Varieties. Detailed list of the antibody used is available in Table 1 (supplementary data). In green the antibodies for pectic polysaccharides (homogalacturonans HG, rhamnogalacturonans (RGI), and side chains (arabinans, galactans and arabinogalactans), in yellow the antibodies for hemicellulosic polysaccharides (mannans, glucan/xyloglucan, and xylans), and in red the antibodies for the glycoproteins (Arabinogalactan-Proteins (AGP) and extensins). 


\section{Supplementary data}
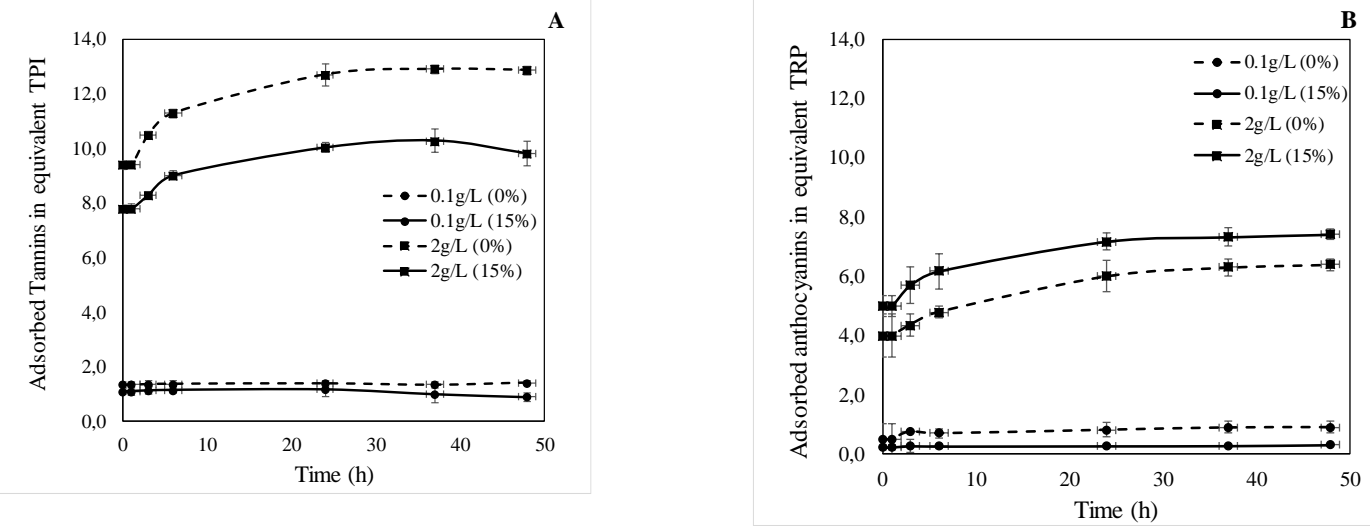

Supplementary Figure 1. Adsorption kinetics at 0.1 and $2 \mathrm{gL}^{-1}$ of A) tannins and B) Anthocyanins on the fresh Flesh Water-Insoluble Material (FWIM) of Carignan. Experiments were performed in 0 and $15 \%$ of ethanol model solutions, using the FWIM of $1.1 \mathrm{~g}$ of fresh flesh per $\mathrm{mL}$ of solution. Results are expressed in equivalent Total Polyphenol Index (TPI) for tannins and equivalent Total Red Pigments (TRP) for anthocyanins. 


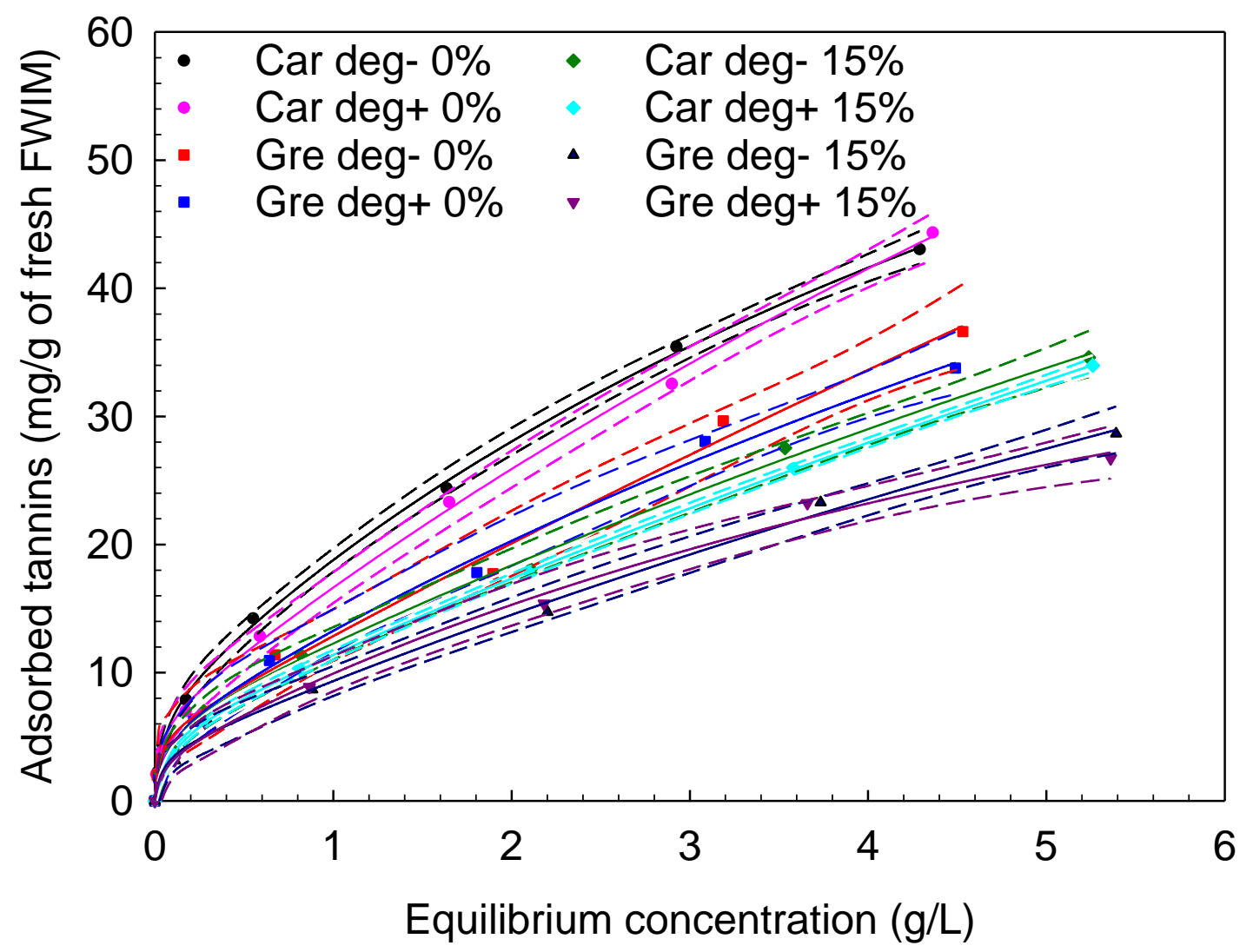

Supplementary Figure 2. Adsorption isotherms fitted with the two-site saturation binding model (solid lines) and the 95\% confidence interval (dashed lines)

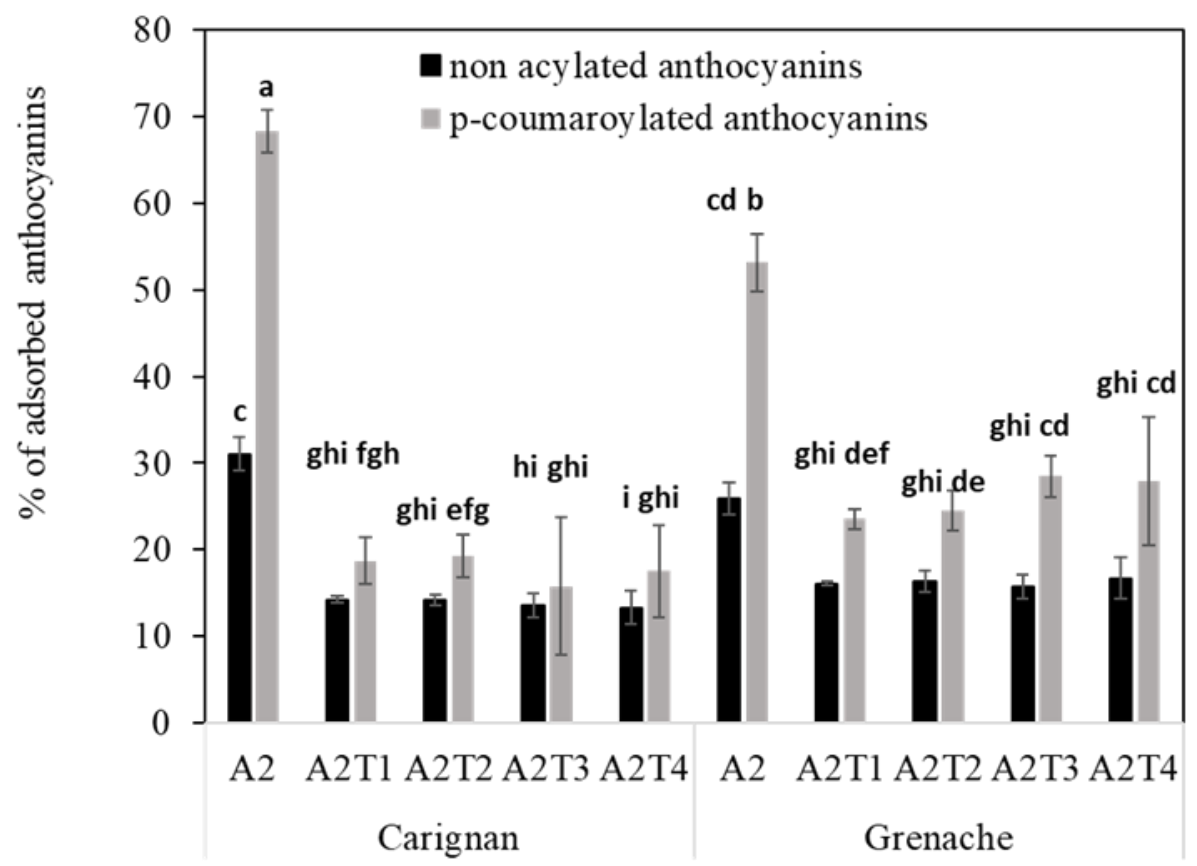

Supplementary Figure 3. Percentage of adsorbed non-acylated and $p$-coumaroylated anthocyanins on fresh Flesh Water Insoluble Material (FWIM) at different tannin concentrations (0, T1: $0.5 \mathrm{gL}^{-1}, \mathrm{~T} 2: 1 \mathrm{gL}^{-1}, \mathrm{~T} 3: 2$ $\mathrm{gL}^{-1}$ and T4: $\left.4 \mathrm{gL}^{-1}\right)$. Experiments were performed in the 15\% ethanol model solution and for an anthocyanin concentration of $2 \mathrm{gL}-1$. 
Supplementary Table 1. List of monoclonal antibodies (mAbs) and CBMs used for the comprehensive microarray polymer profiling (CoMPP) analysis (taken from Weiller F., Gerber L., Trygg J., Fangel J-U., Willats W.G.T., Driouich A., Vivier M.A., Moore J-P. Overexpression of VviPGIP1 and NtCAD14 in Tobacco Screened Using Glycan Microarrays Reveals Cell Wall Reorganisation in the Absence of Fungal Infection. Vaccines 2020, 8, 388; doi:10.3390/vaccines8030388.)

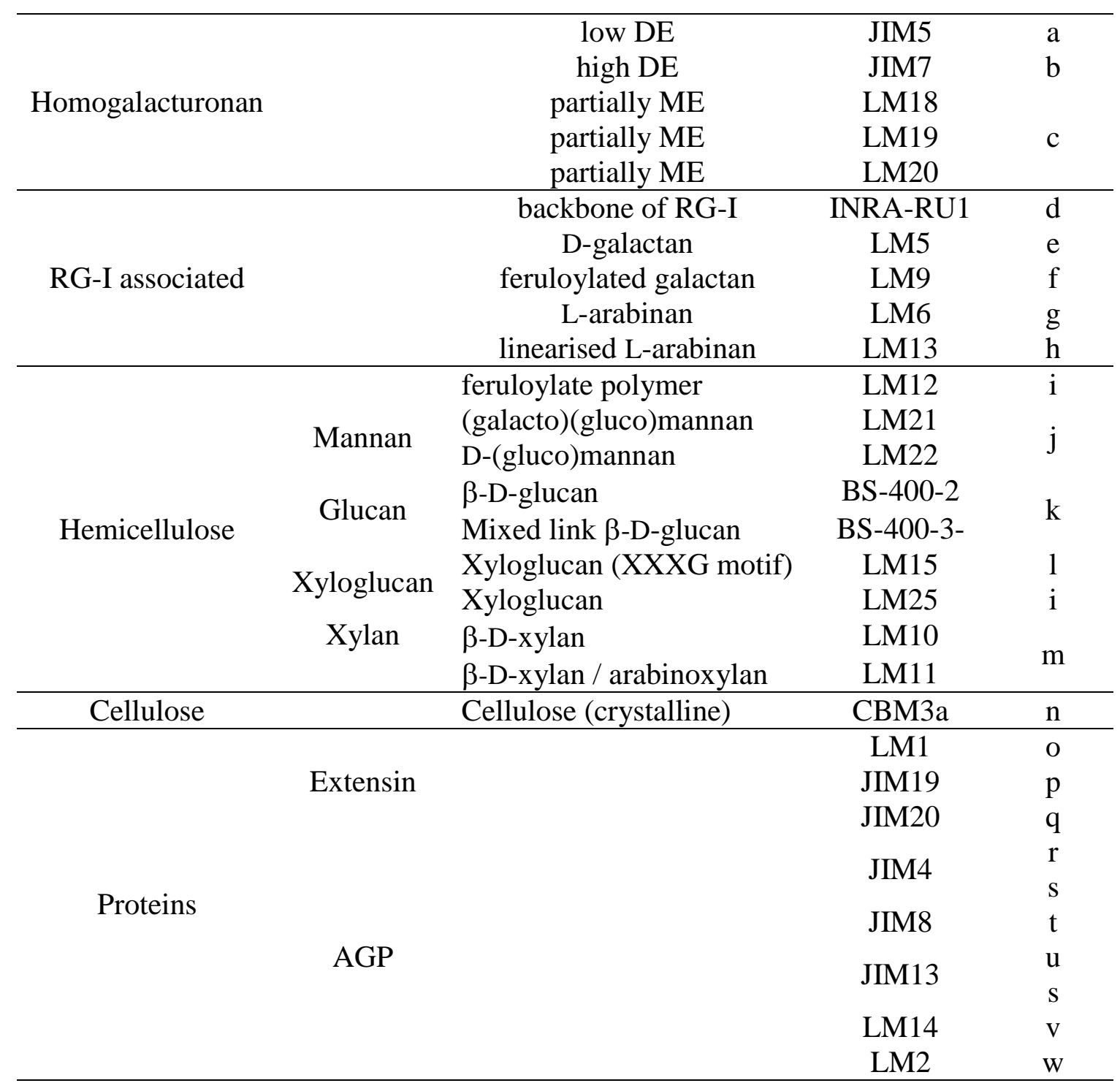

a Knox, J.P.; Linstead, P.; King, J.; Cooper, C.; Roberts, K. Pectin esterification is spatially regulated both within cell walls and between developing tissues of root apices. Planta 1990, 181, 512-521.

b Clausen, M.H.; Willats, W.G.T.; Knox, J.P. Synthetic methyl hexagalacturonate hapten inhibitors of anti-homogalacturonan monoclonal antibodies LM7, JIM5 and JIM7. Carbohydr. Res. 2003, 338, 1797-1800.

c Verhertbruggen, Y.; Marcus, S.E.; Haeger, A.; Ordaz-Ortiz, J.J.; Knox, J.P. An extended set of monoclonal antibodies to pectic homogalacturonan. Carbohydr. Res. 2009, 344, 1858-1862.

d Ralet, M.-C.; Tranquet, O.; Poulain, D.; Moïse, A.; Guillon, F. Monoclonal antibodies to rhamnogalacturonan I backbone. Planta 2010, 231, 1373-1383.

e Jones, L.; Seymour, G.B.; Knox, J.P. Localization of pectic galactan in tomato cell walls using a monoclonal antibody specific to $(1 \rightarrow 4)-\beta$-D-galactan. Plant Physiol. 1997, 113, 1405-1412. Vaccines 2020, 8, 38821 of 23

f Clausen, M.H.; Ralet, M.-C.; Willats, W.G.T.; McCartney, L.; Marcus, S.E.; Thibault, J.-F.; Knox, J.P. A monoclonal antibody to feruloylated-(1 $\rightarrow 4)-\beta$-D-galactan. Planta 2004, 219, 1036-1041. 
g Willats, W.G.T.; Marcus, S.E.; Knox, J.P. Generation of a monoclonal antibody specific to (1!5)-1-arabinan. Carbohydr. Res. 1998, 308, 149-152.

h Verhertbruggen, Y.; Marcus, S.E.; Haeger, A.; Verhoef, R.; Schols, H.A.;McCleary, B.V.; McKee, L.; Gilbert, H.J.; Knox, J.P. Developmental complexity of arabinan polysaccharides and their processing in plant cell walls. Plant J. 2009, 59, 413-425.

i Pedersen, H.L.; Fangel, J.U.; McCleary, B.; Ruzanski, C.; Rydahl, M.G.; Ralet, M.-C.; Farkas, V.; von Schantz, L.; Marcus, S.E.; Andersen, M.C.F.; et al. Versatile high resolution oligosaccharide microarrays for plant glycobiology and cell wall research. J. Biol. Chem. 2012, 287, 3942939438.

j Marcus, S.E.; Blake, A.W.; Benians, T.A.S.; Lee, K.J.D.; Poyser, C.; Donaldson, L.; Leroux, O.; Rogowski, A.; Petersen, H.L.; Boraston, A.; et al. Restricted access of proteins to mannan polysaccharides in intact plant cell walls. Plant J. 2010, 64, 191-203.

k Meikle, P.J.; Bonig, I.; Hoogenraad, N.J.; Clarke, A.E.; Stone, B.A. The location of (1!3)-_-glucans in the walls of pollen tubes of Nicotiana alata using a (1!3)-_-glucan-specific monoclonal antibody. Planta 1991, 185, 1-8.

1 Marcus, S.E.; Verhertbruggen, Y.; Hervé, C.; Ordaz-Ortiz, J.J.; Farkas, V.; Pedersen, H.L.; Willats, W.G.T.; Knox, J.P. Pectic homogalacturonan masks abundant sets of xyloglucan epitopes in plant cell walls. BMC Plant Biol. 2008, 8, 60

m McCartney, L.; Marcus, S.E.; Knox, J.P. Monoclonal antibodies to plant cell wall xylans and arabinoxylans. J. Histochem. Cytochem. 2005, 53, 543-546

n Tormo, J.; Lamed, R.; Chirino, A.J.; Morag, E.; Bayer, E.A.; Shoham, Y.; Steitz, T.A. Crystal structure of a bacterial family-III cellulose-binding domain: A general mechanism for attachment to cellulose. EMBO J. 1996, 15, 5739-5751.

o Smallwood, M.; Martin, H.; Knox, J.P. An epitope of rice threonine- and hydroxyproline-rich glycoprotein is common to cell wall and hydrophobic plasma-membrane glycoproteins. Planta 1995, 196, 510-522.

p Smallwood, M.; Beven, A.; Donovan, N.; Neill, S.J.; Peart, J.; Roberts, K.; Knox, J.P. Localization of cell wall proteins in relation to the developmental anatomy of the carrot root apex. Plant $\mathrm{J}$. 1994, 5, 237-246.

q Knox, J.P.; Peart, J.; Neill, S. Identification of novel cell surface epitopes using a leaf epidermalstrip assay system. Planta 1995, 196]

r Knox, J.P.; Day, S.; Roberts, K. A set of cell surface glycoproteins forms an early position, but not cell type, in the root Apical Carota L. Development 1989, 106.

s Yates, E.A.; Valdor, J.-F.; Haslam, S.M.; Morris, H.R.; Dell, A.; Mackie, W.; Knox, J.P. Characterization of carbohydrate structural features recognized by anti-arabinogalactan-protein monoclonal antibodies. Glycobiology 1996, 6, 131-139.

t McCabe, P.F.; Valentine, T.A.; Forsberg, L.S.; Pennell, R.I. Soluble signals from cells identified at the cell wall establish a developmental pathway in carrot. Plant Cell 1997, 9, 2225-2241.

u Knox, J.P.; Linstead, P.; Cooper, J.P.C.; Roberts, K. Developmentally regulated epitopes of cell surface arabinogalactan proteins and their relation to root tissue pattern formation. Plant J. 1991, $1,317-326$.

v Moller, I.; Marcus, S.E.; Haeger, A.; Verhertbruggen, Y.; Verhoef, R.; Schols, H.; Ulvskov, P.; Mikkelsen, J.D.; Knox, J.P.;Willats,W. High-throughput screening of monoclonal antibodies against plant cell wall glycans by hierarchical clustering of their carbohydrate microarray binding profiles. Glycoconj. J. 2008, 25, 37-48.

w Smallwood, M.; Yates, E.A.; Willats, W.G.T.; Martin, H.; Knox, J.P. Immunochemical comparison of membrane-associated and secreted arabinogalactan-proteins in rice and carrot. Planta 1996, $198,452-459$. 
Supplementary Table 2. Parameters derived from one-site and two-site saturation binding curve fitting when the adsorbed amounts of tannins are calculated per gram of Alcohol Insoluble Solids (using Table 3 data).

\begin{tabular}{|c|c|c|c|c|c|c|c|c|}
\hline & $\begin{array}{l}\mathrm{B}_{\max } \\
\text { (mg tannin } \\
/ \mathrm{g} \text { of flesh) }\end{array}$ & $\begin{array}{l}\mathrm{K}_{\mathrm{d}} \\
(\mathrm{g} / \mathrm{L})\end{array}$ & $\begin{array}{l}\text { Adjusted } \\
\mathrm{R}^{2}\end{array}$ & $\begin{array}{l}\mathrm{B}_{\max 1} \\
\text { (mg tannin / } \\
\mathrm{g} \text { of flesh) }\end{array}$ & $\begin{array}{l}\mathrm{K}_{\mathrm{d} 1} \\
(\mathrm{~g} / \mathrm{L})\end{array}$ & $\begin{array}{l}\mathrm{B}_{\max 2} \\
\text { (mg tannin } \\
\mathrm{g} \text { of flesh) } \\
\end{array}$ & $\begin{array}{l}\mathrm{K}_{\mathrm{d} 2} \\
(\mathrm{~g} / \mathrm{L})\end{array}$ & $\begin{array}{l}\text { Adjusted } \\
\mathrm{R}^{2}\end{array}$ \\
\hline Car Deg- 0\% & 1111 & 1.254 & 0.9774 & 230.8 & 0.0568 & 1508 & 4.933 & 0.9979 \\
\hline Car Deg+ 0\% & 1024 & 1.349 & 0.9770 & 121.3 & 0.0135 & 1204 & 3.252 & 0.9994 \\
\hline Gre Deg-0\% & 1220 & 1.734 & 0.9679 & 201.2 & 0.0445 & 2397 & 10.24 & 0.9959 \\
\hline Gre Deg+ 0\% & 1090 & 1.523 & 0.9781 & 217.7 & 0.0961 & 1797 & 8.029 & 0.9984 \\
\hline $\begin{array}{l}\text { Car Deg- } \\
15 \%\end{array}$ & 849 & 1.992 & 0.9783 & 114.5 & 0.0594 & 1132 & 6.031 & 0.9988 \\
\hline $\begin{array}{l}\text { Car Deg+ } \\
15 \%\end{array}$ & 915 & 1.907 & 0.9821 & 140.9 & 0.0904 & 1224 & 6.223 & 0.9998 \\
\hline $\begin{array}{l}\text { Gre Deg- } \\
15 \%\end{array}$ & 898 & 2.194 & 0.9785 & 101.0 & 0.0346 & 1189 & 6.014 & 0.9989 \\
\hline $\begin{array}{l}\text { Gre Deg+ } \\
15 \%\end{array}$ & 990 & 2.139 & 0.9801 & 125.0 & 0.0598 & 1311 & 6.141 & 0.9989 \\
\hline
\end{tabular}




\begin{tabular}{|c|c|c|c|c|c|c|c|c|c|c|c|c|c|c|c|c|c|c|c|c|c|c|c|c|c|c|c|c|c|}
\hline & p-value $(5 \%)$ & 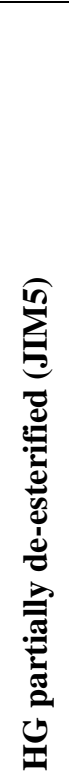 & 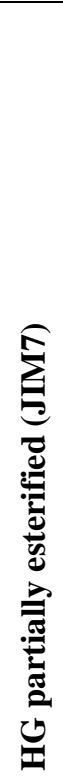 & 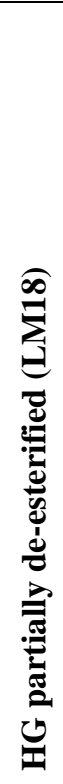 & 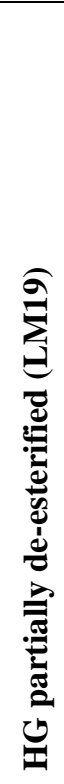 & 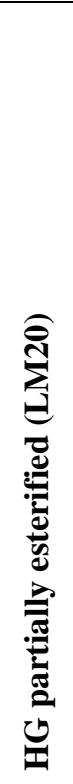 & 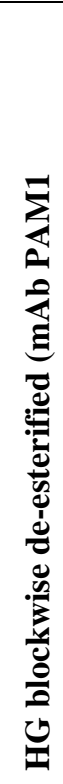 & 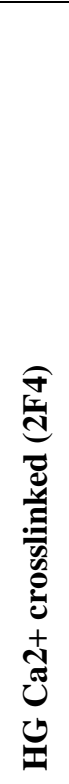 & 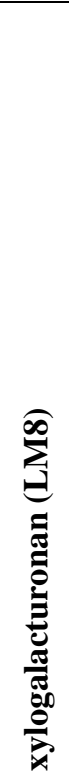 & 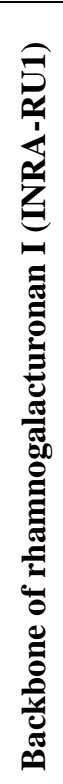 & 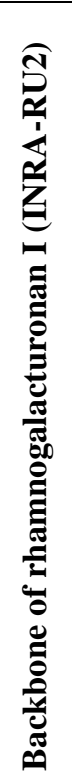 & 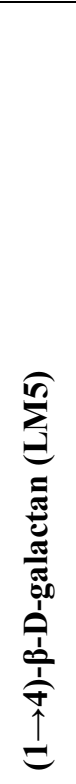 & 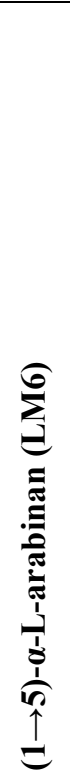 & 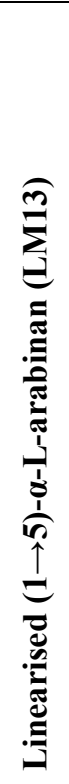 & 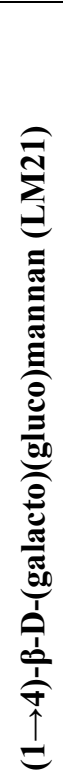 & 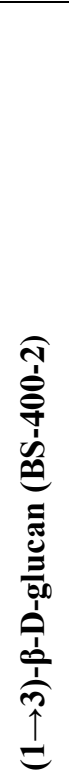 & 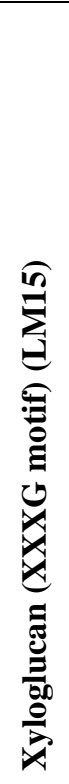 & 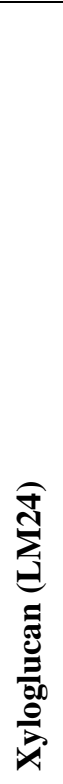 & 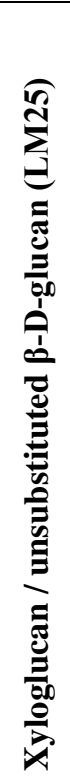 & 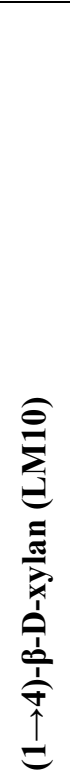 & 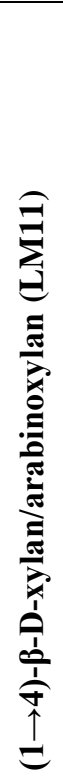 & 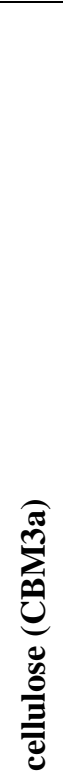 & 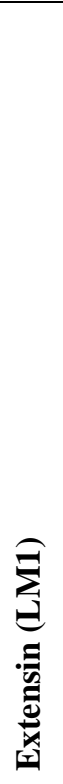 & 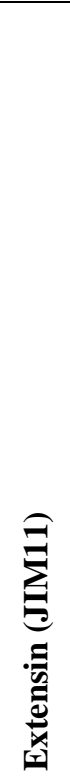 & 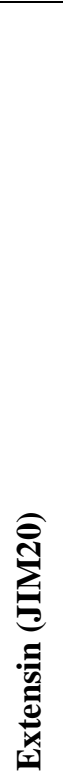 & 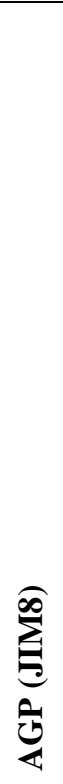 & $\underbrace{\stackrel{n}{\Xi}}_{\vec{b}}$ & 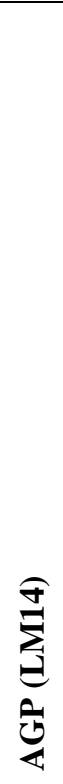 & 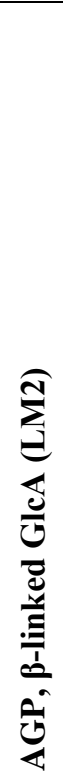 \\
\hline & Factors & & & & & & & & & & & & & & & & & & & & & & & & & & & & \\
\hline \multirow{3}{*}{$\begin{array}{l}\text { CDTA- } \\
\text { Fraction }\end{array}$} & Variety & 0.0 & 0.0 & 0.0 & 0.0 & 0.0 & 0.3 & 0.0 & 0.2 & 0.7 & 0.4 & 0.0 & 0.0 & 0.0 & 0.5 & 0.0 & 0.4 & 0.7 & 0.0 & 0.2 & 0.3 & 0.4 & 0.0 & 0.0 & 0.0 & 0.0 & 0.0 & 0.0 & 0.1 \\
\hline & $\begin{array}{l}\text { Percentage of } \\
\text { sugar }\end{array}$ & 1.0 & 0.8 & 0.2 & 0.6 & 0.1 & 0.5 & 0.1 & 0.1 & 0.3 & 0.3 & 0.6 & 0.8 & 0.0 & 0.3 & 0.1 & 0.2 & 0.3 & 0.0 & 0.4 & 0.9 & 0.6 & 0.8 & 0.4 & 1.0 & 0.1 & 0.2 & 0.1 & 0.9 \\
\hline & $\begin{array}{l}\text { Variety*Percentage } \\
\text { of sugar }\end{array}$ & 0.8 & 0.9 & 0.5 & 0.5 & 0.3 & 0.7 & 0.0 & 0.2 & 0.3 & 0.4 & 0.6 & 0.2 & 0.1 & 0.9 & 0.0 & 0.1 & 0.7 & 0.6 & 0.9 & 0.7 & 0.2 & 0.9 & 0.2 & 0.9 & 0.0 & 0.0 & 0.0 & 0.8 \\
\hline \multirow{3}{*}{$\begin{array}{l}\mathrm{NaOH}- \\
\text { Fraction }\end{array}$} & Variety & 0.5 & 0.9 & 0.4 & 0.1 & 0.4 & 1.0 & 0.4 & 0.2 & 0.0 & 0.0 & 0.0 & 0.0 & 0.0 & 0.2 & 0.0 & 0.0 & 0.5 & 0.6 & 0.0 & 0.3 & 0.2 & 0.0 & 0.0 & 0.0 & 0.6 & 0.6 & 0.0 & 0.8 \\
\hline & $\begin{array}{l}\text { Percentage of } \\
\text { sugar }\end{array}$ & 0.3 & 0.2 & 0.3 & 0.9 & 0.8 & 0.2 & 0.2 & 0.3 & 0.2 & 0.1 & 0.6 & 0.1 & 0.2 & 0.3 & 0.0 & 0.7 & 0.2 & 0.1 & 0.7 & 0.2 & 0.6 & 0.7 & 0.1 & 0.1 & 0.0 & 0.0 & 0.0 & 0.2 \\
\hline & $\begin{array}{l}\text { Variety*Percentage } \\
\text { of sugar }\end{array}$ & 0.2 & 0.9 & 0.2 & 0.5 & 0.6 & 0.3 & 0.4 & 0.2 & 0.7 & 0.5 & 0.3 & 0.3 & 0.3 & 0.5 & 0.1 & 0.5 & 1.0 & 1.0 & 0.2 & 0.5 & 0.6 & 0.1 & 0.4 & 0.4 & 0.8 & 0.1 & 0.0 & 0.1 \\
\hline
\end{tabular}

Supplementary Table 3. Factorial ANOVA assessed on the raw data of the heatmap table from the AIS samples of the flesh cell walls of Carignan and Grenache. 